\title{
قراءة تحليلية نقدية في تولي المرأة منصب القضاء
}

\section{هدى هلال}

\begin{abstract}
الملتخص

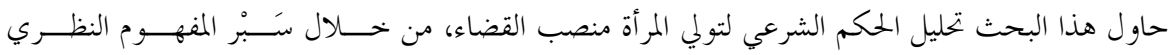

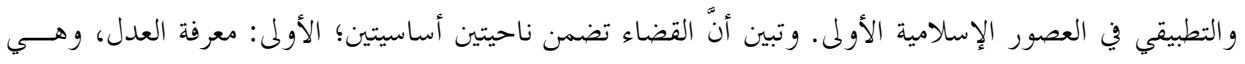

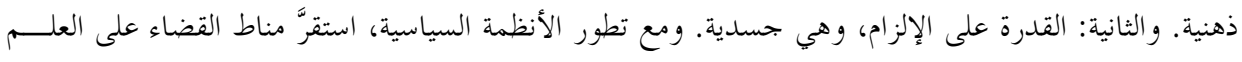

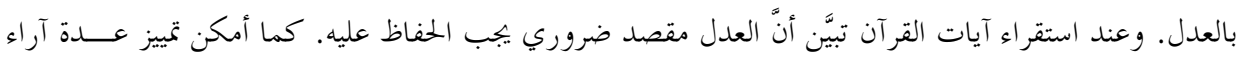

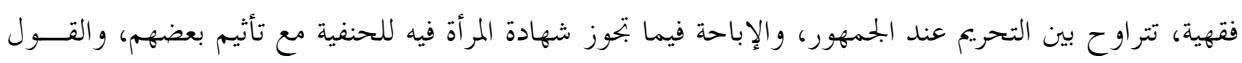

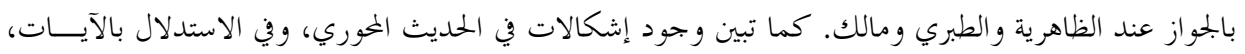

وفي القياس.

الكلمات المفتاحية: المرأة، منصب القضاء، العدل، علة القضاء.
\end{abstract}

\begin{abstract}
This research tries to analyze the legal ruling of appointing woman as a judge and probes the matter in its theoretical and practical dimensions in previous Islamic eras. It shows that judgment consisted of two essential points; the knowledge of justice, which is a mental ability, and the enforcement of justice, which is a practical ability. With the development of political systems focus of judgment has rested on knowledge of justice. Comprehensive survey of Quranic verses shows that justice is an essential intention that must be maintained. This research identified several rulings, ranging from prohibition to permission of whether a woman is allowed to have a judiciary position. It shows also problems in applying Quranic verses, prophetic tradition, and analogical deduction.
\end{abstract}

Keywords: appointing woman as a judge, justice is an effective cause for judgment.

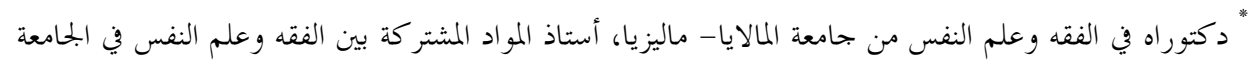

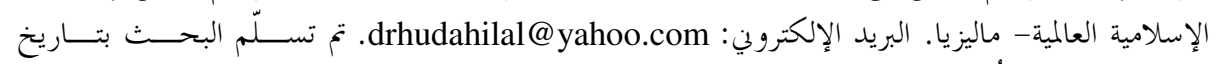

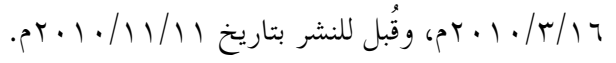




\section{مقدمة:}

تدور البحوث التي تناولت الحكم الشرعي لتولي المرأة منصب القضاء في دائـــرة

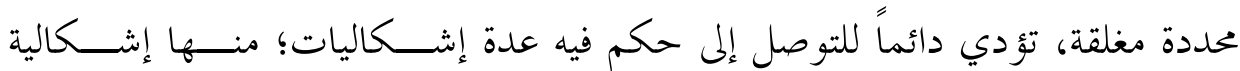

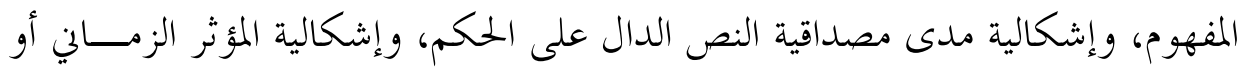
العرف السائد، وإشكالية المؤثر المكاني، أو الظروف التي أدت إلى هذا الحكم، و الوقائع التاريخية الملازمة للحكم.

وإذا لم تنهض دراسة تسبر هذه الإشكاليات، وتناقش الجذور العقلية للأحكـــام

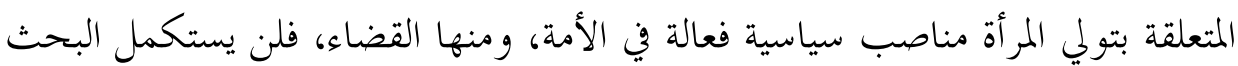

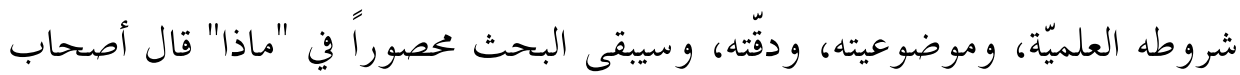

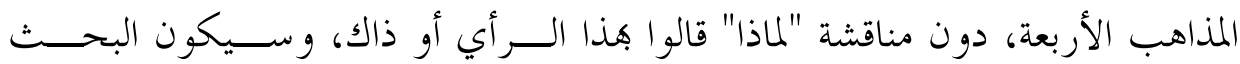
متحيزًا.

إذاً، تكمن الإشكالية في تحديد الحكم الشرعي الصحيح لتــولي المـــرأة منصـــب القضاء في الإجابة عن سؤ ال: هل يمكن تحديد مناط القضاء من خلال استقر اء المفاهيم

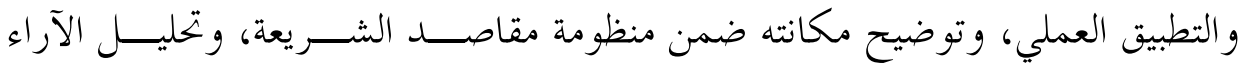

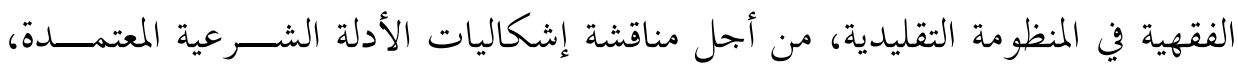
للخرو ج من الدائرة المغلقة؟ واعتمدت هذه الدراسة المنهج الاستقرائي لكتب التاريخ،

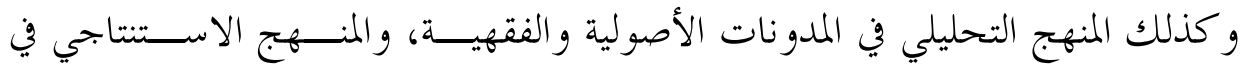
المناقشة.

\section{أولاً: مفهوم القضاء نظرياً وعملياً}

\section{ا ـ المفهوم النظري للقضاء وتحليلاته في المذاهب الأربعة:}

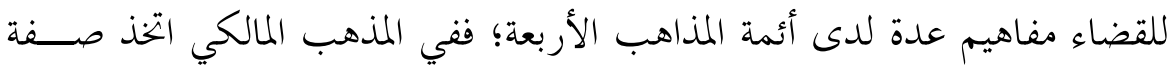

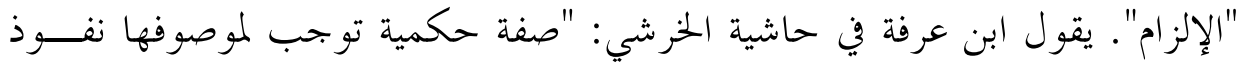




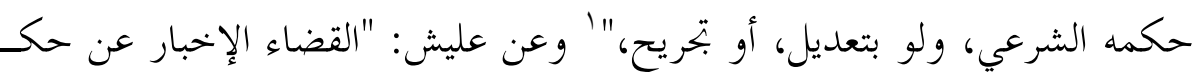

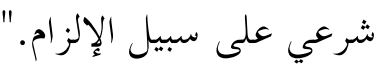

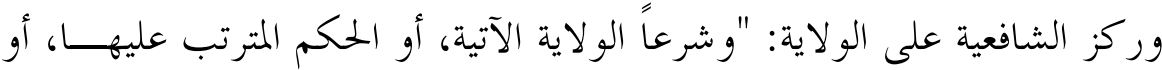

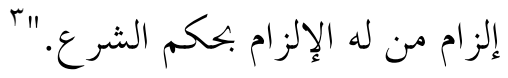

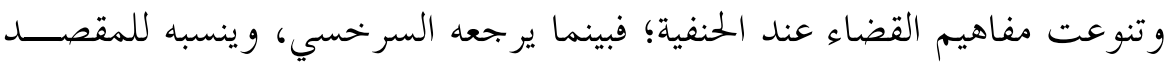

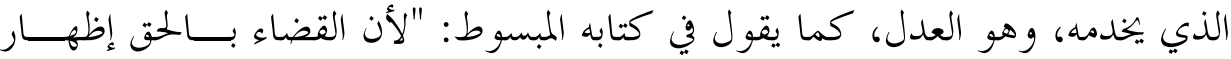

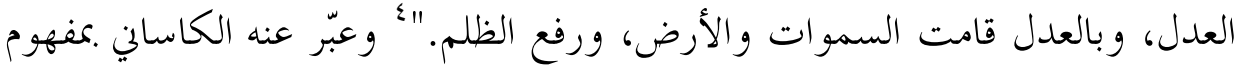

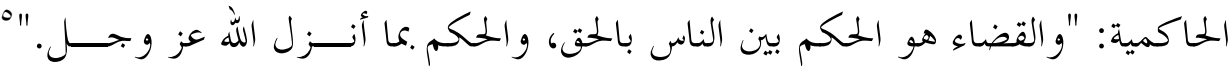

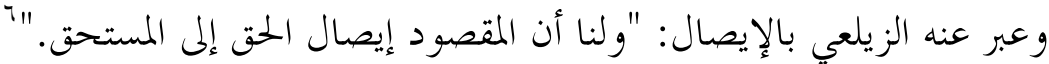

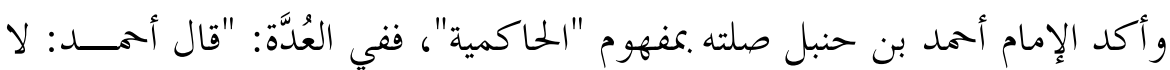

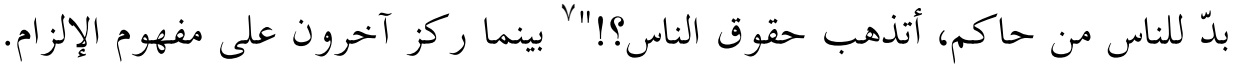

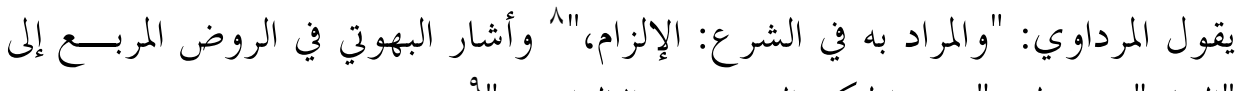

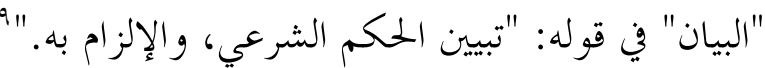

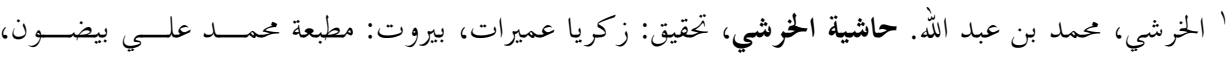

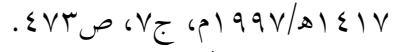

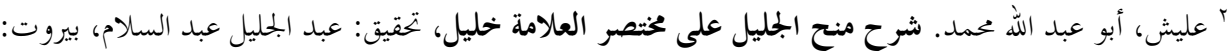

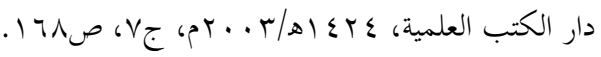

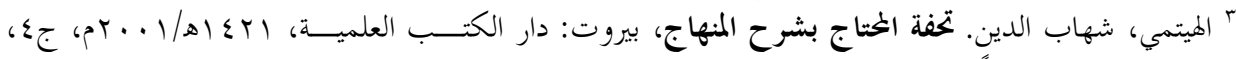

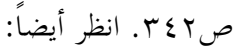
- العجيلي، سليمان بن عمر . حاشية الجمل على شرح المنهج، تحقيق: عبد الرزاق غالب المهدي، بيروت: دار

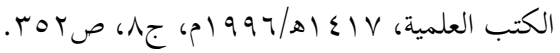

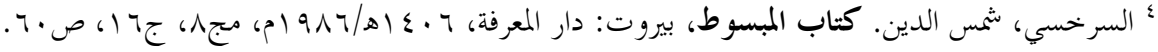

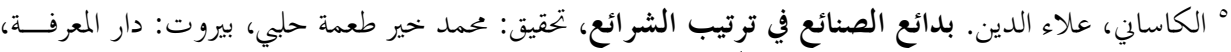

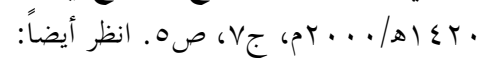
- العين، كمود بن أممد المعروف ببدر الدين. البناية شرح الهداية، تحقيق: أئن صالح شعبان، بــيروت: دار

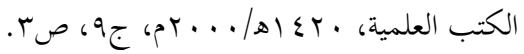

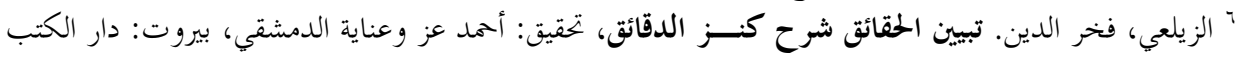

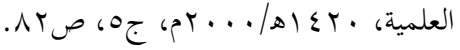

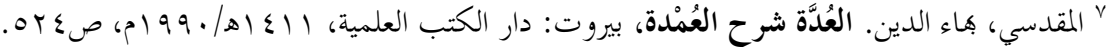

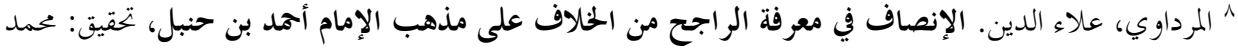

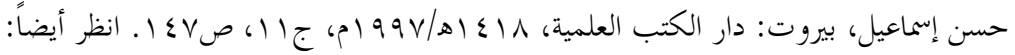


باستقراء ما سبق، يمكن القول إن جميع المذاهب عسـدّت مفهـــوم الحاكميسـة في

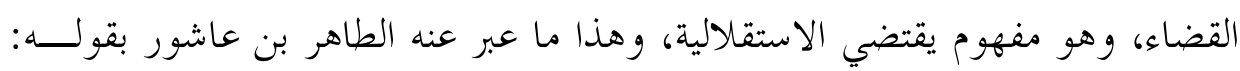

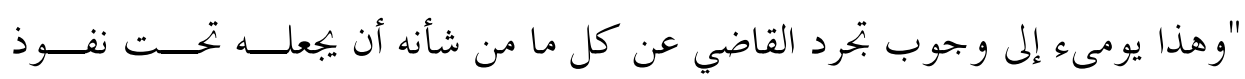

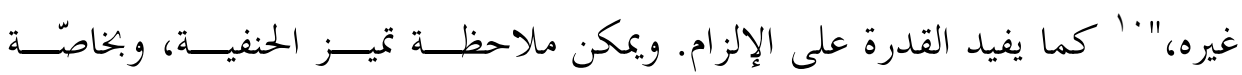

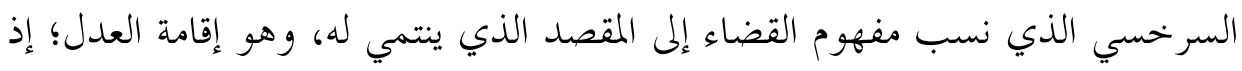

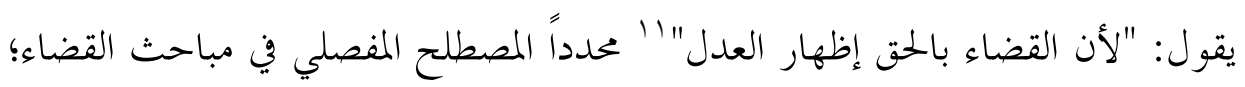

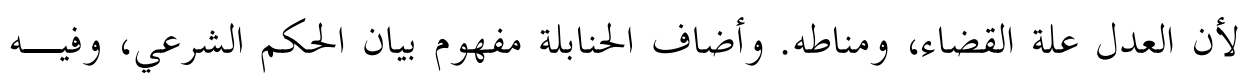

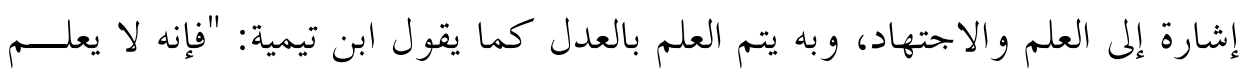

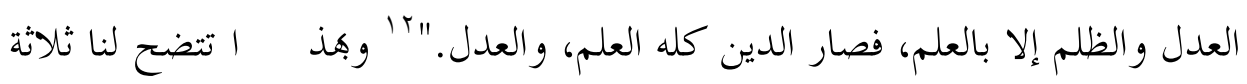

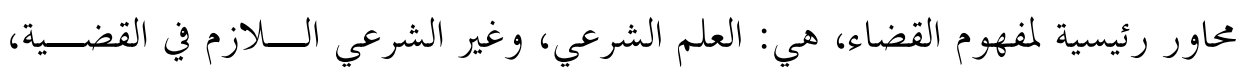

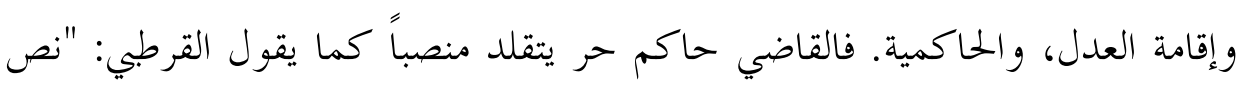

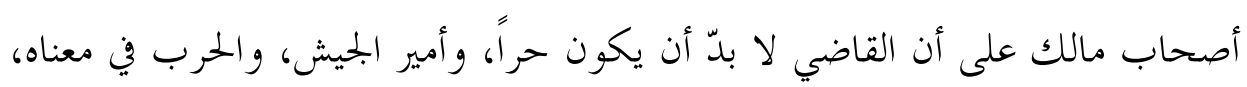

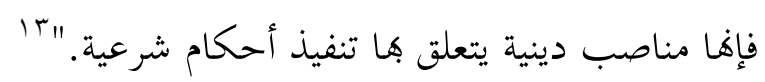

r. المطلب الثاني: المفهوم التطبيقي للقضاء في عصر النبي والعصور الإسلامية

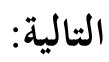

- البهوتي، منصور بن يونس. كشاف القناع عن متن الإقناع، تعقيق: عمد حسن إسماعيـل، بــيروت: دار

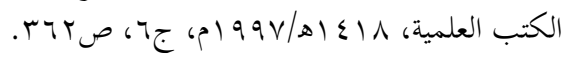

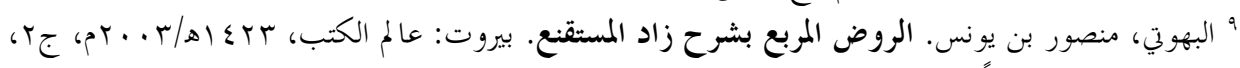
صجا \&. انظر أيضاً:

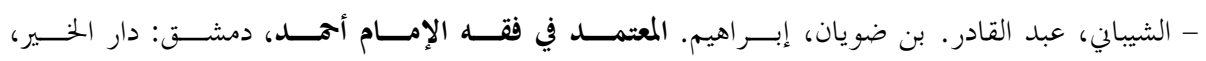
每

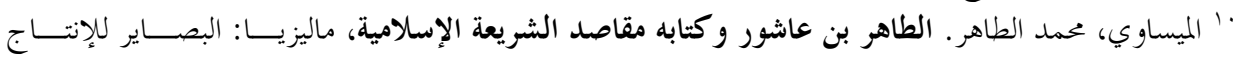

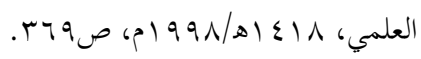

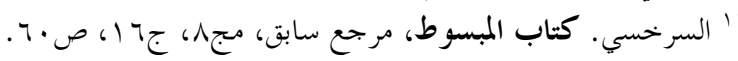

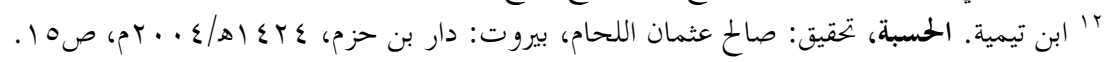

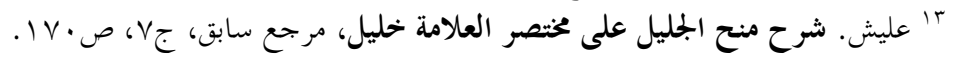




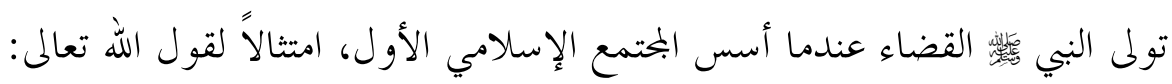

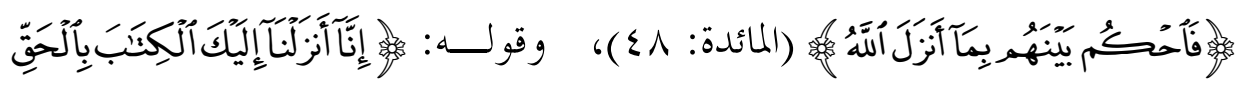

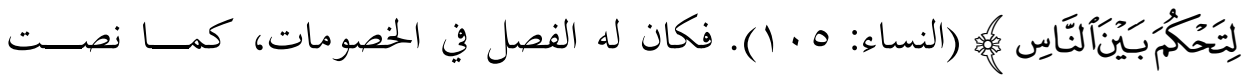

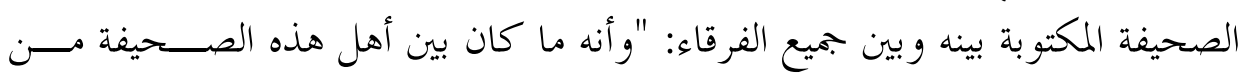

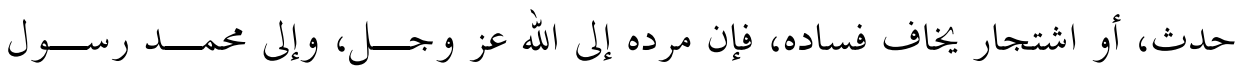

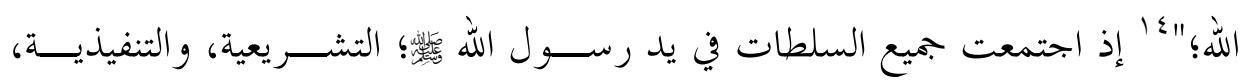

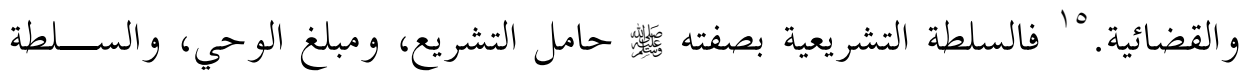

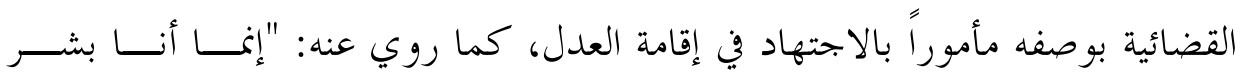

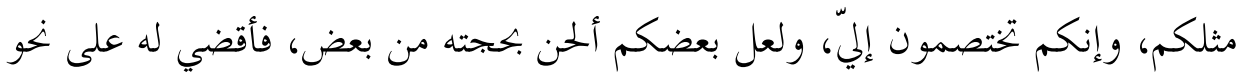

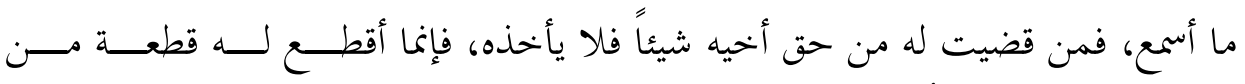

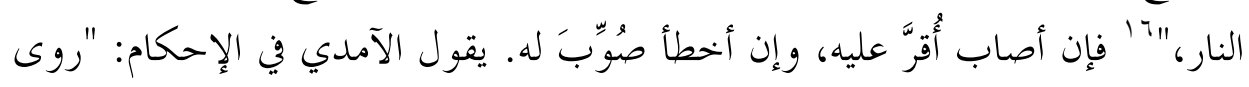

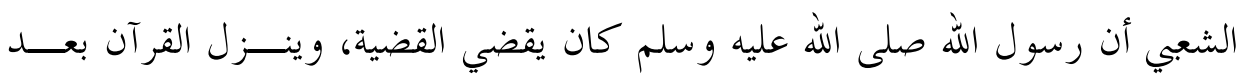

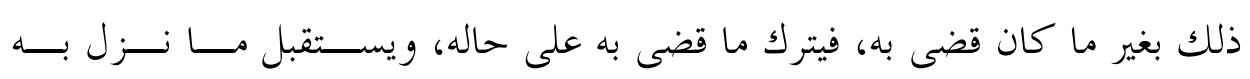

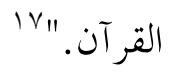

وجعل الله سبحانه وتعالى السلطة التنفيذية في يد الرسول صلى الله عليه وســلم

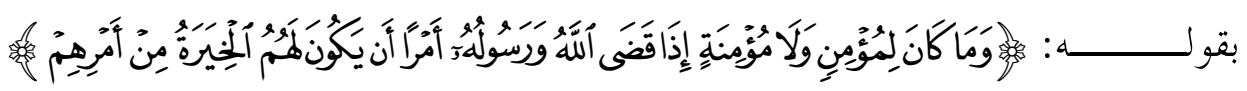

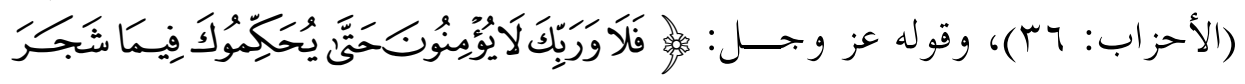

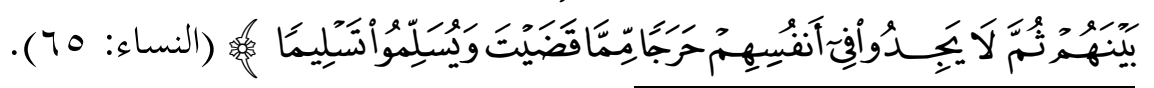

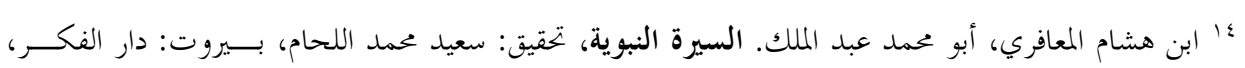

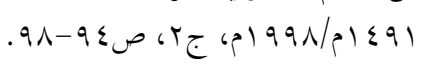

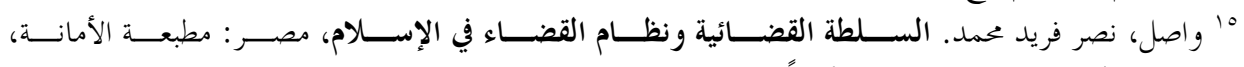

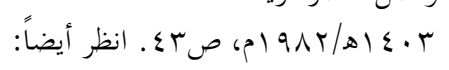

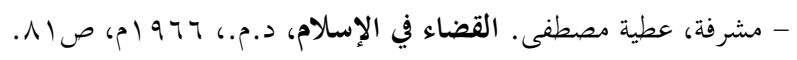

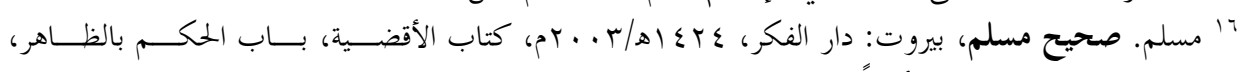

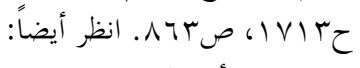
- النووي، أبو زكريا ييى. شرح النووي على صحيح مسلم، القــاهرة: المطبعـة المصــرية، د.ت.، جن، Vl الآمدي. الإحكام في أصول الأحكام، ميدان الأزهر بمصر: مكتبة صبيح، د.ت.، جr، ص اع ا. 


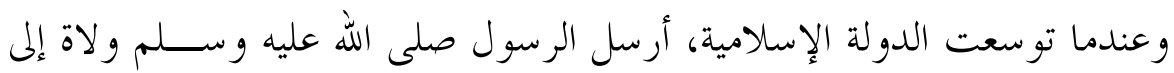

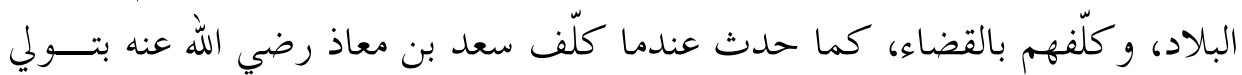

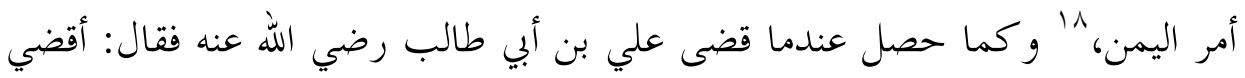

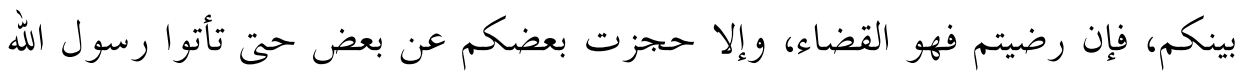

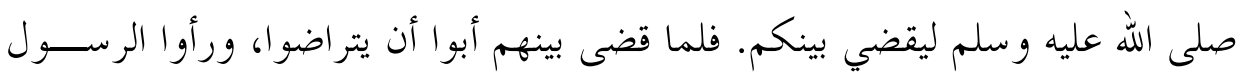

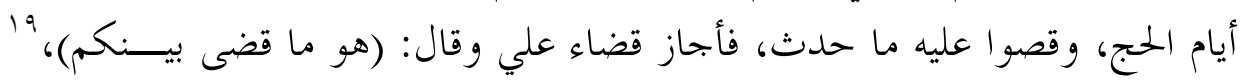

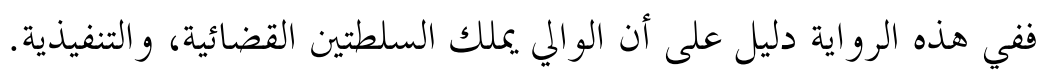

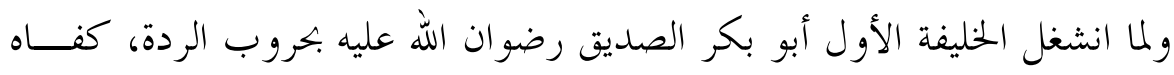

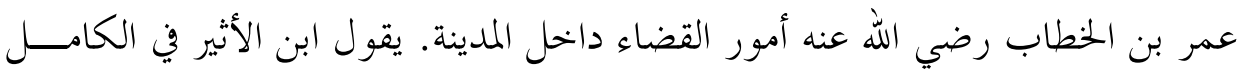

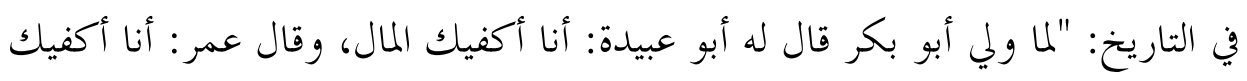

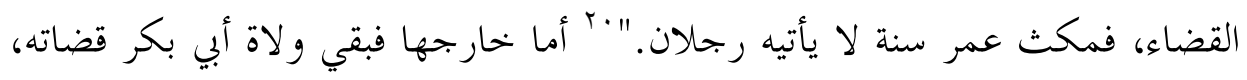

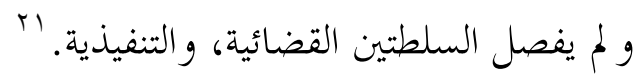

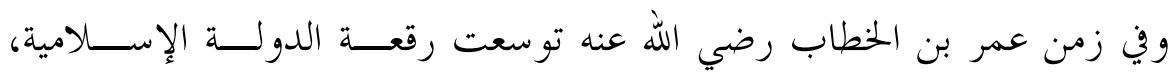

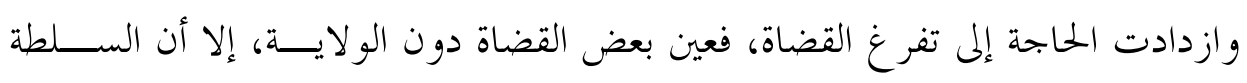

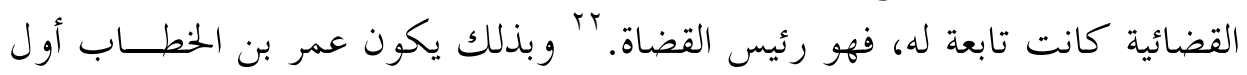

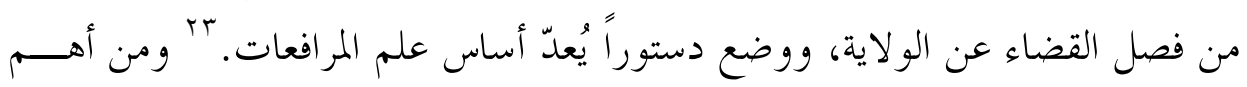

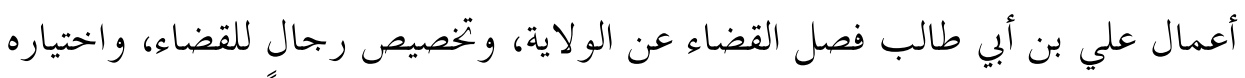
أفضل الرجال من أجل ضمان الحلكم العادل.

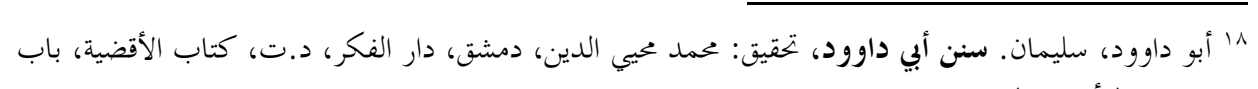

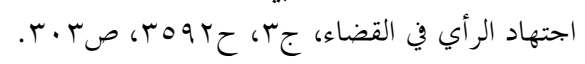

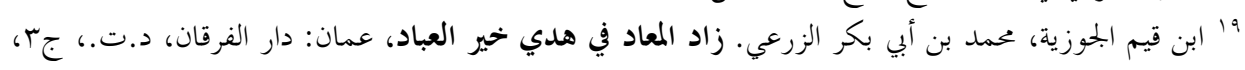

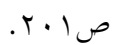

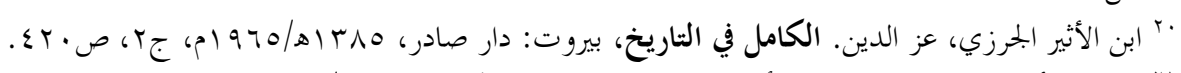

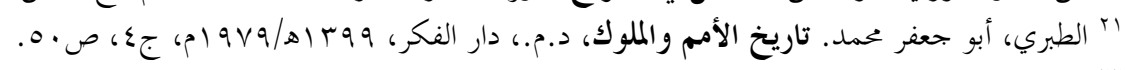

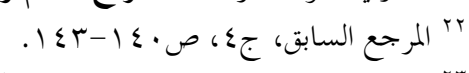

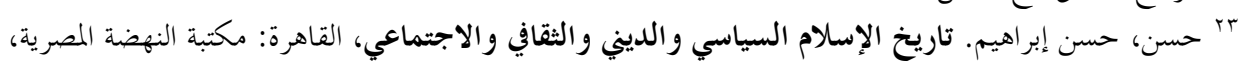
( צ' عزام، عبد العزيز عحمد. النظام القضائي في الإسلام، القاهرة: المؤسسة العربية الحديثة، د.ت.، جا، صع ـ. 


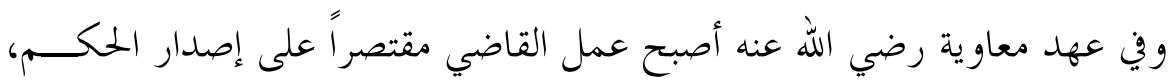

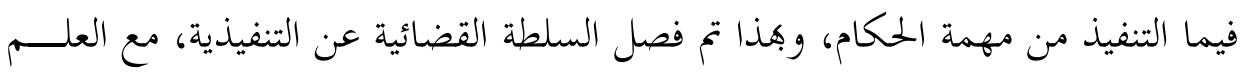

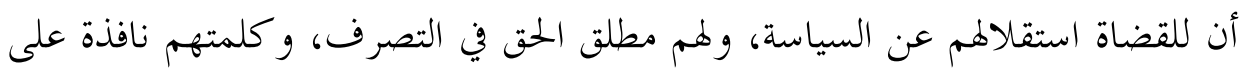

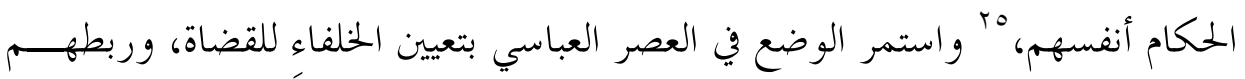

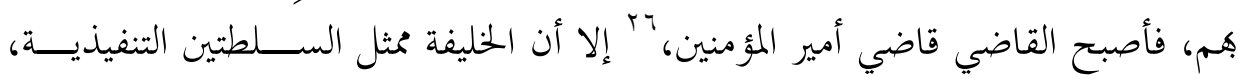
و القضائية.

باستقر اء التطورات التي حصلت لمنصب تولي القضاء، يتبين أن القاضي في السابق

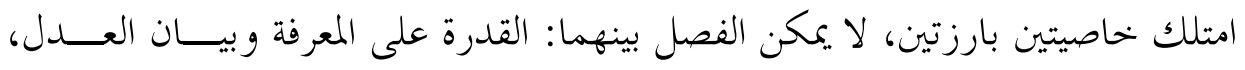

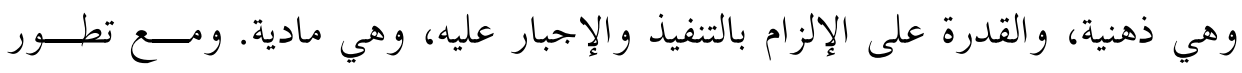

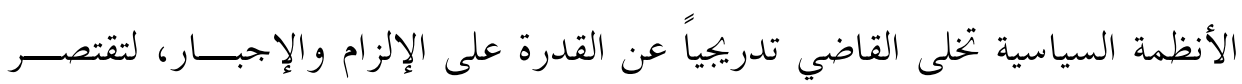
مهمته على بيان الحكم الشرعي العادل، وهذا استقر مناط القضاء على العلم بالعدل.

\section{ثانياً: مكانة العدل ضمن منظومة المقاصد}

\section{1 ـ السمات الرئيسية للعدل التي تؤهله لمرتبة مقاصد الشريعة:}

\section{أ. سبب إرسال الرسل وتشريع الشرائع السماوية تحقيق العدل:}

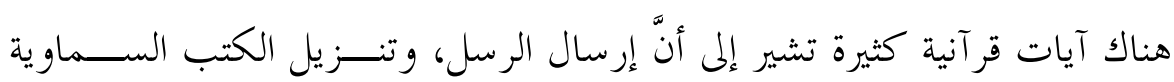

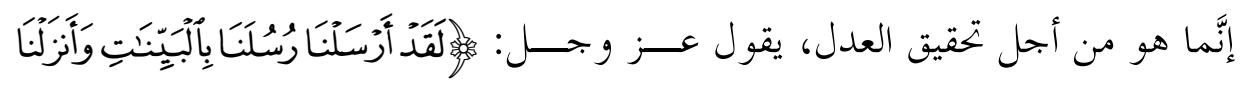

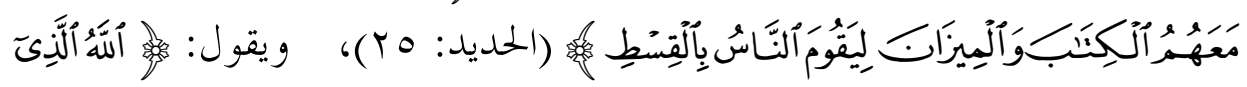

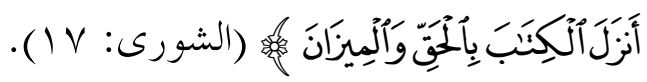

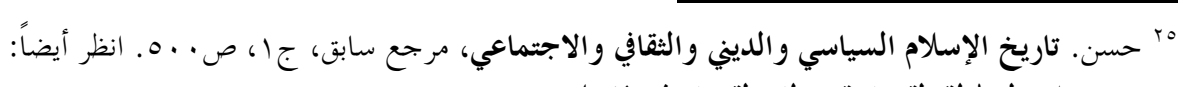

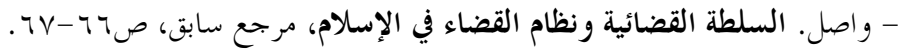

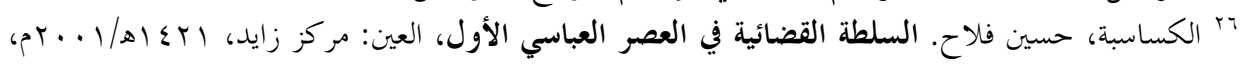




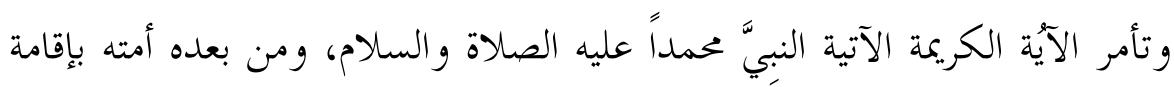

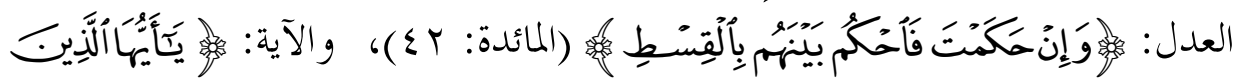

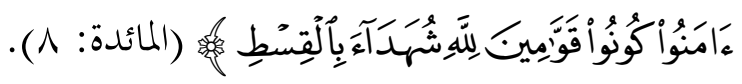

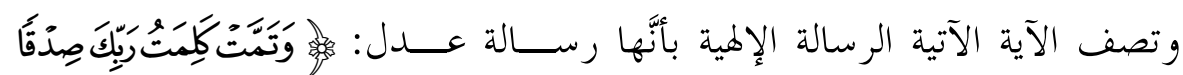

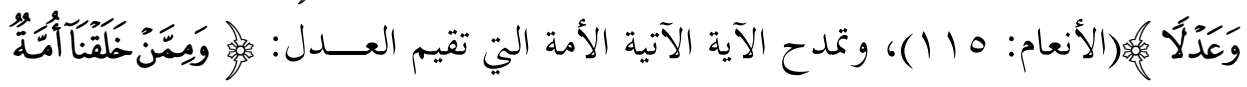

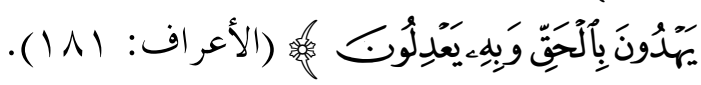

وبهذا تتبين إرادة الشارع بإقامة العدل، يقول الطاهر بن عاشور: "أنبأنا اســتقراء

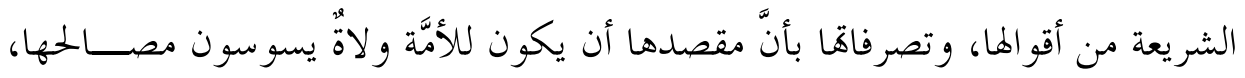

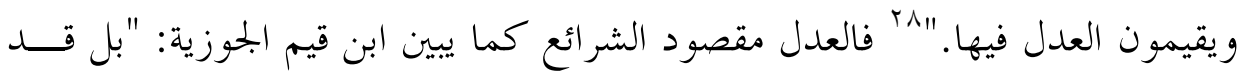

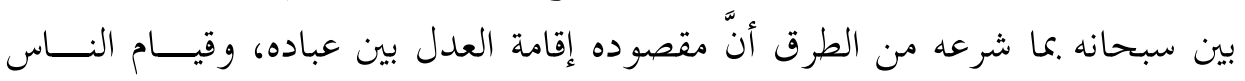

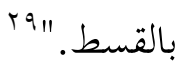

\section{ب. تحقيق العدل سبب نصر الأمم:}

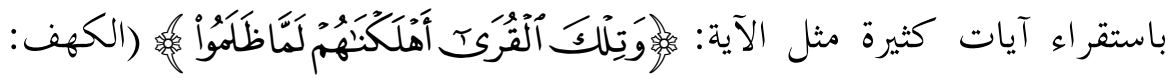

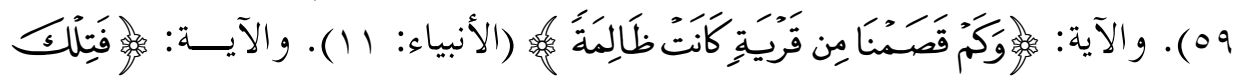

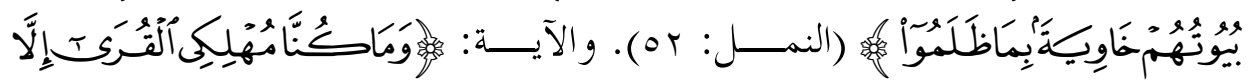

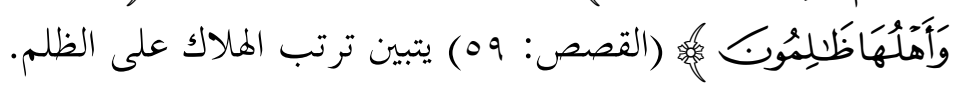
وقد عرض القصصُ القرآني مآلات الظلم، وأنَّهَ سببُ سقوط الدول، واهيارها،

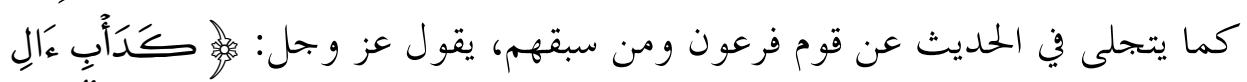

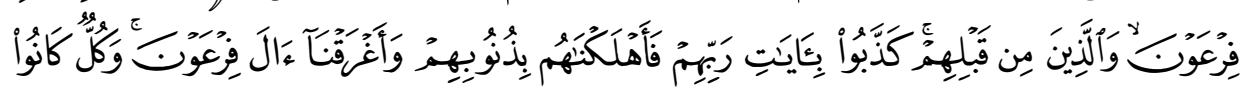

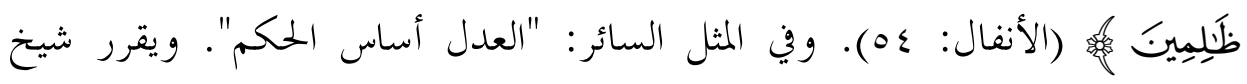

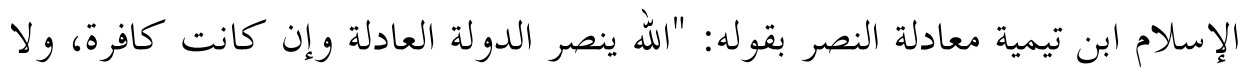

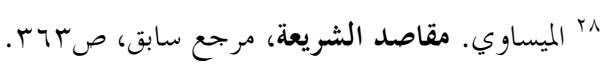

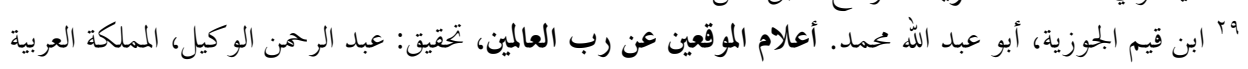

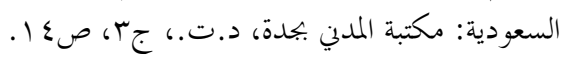




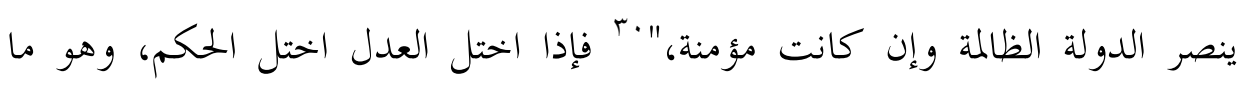

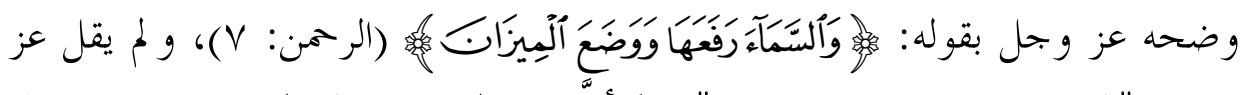

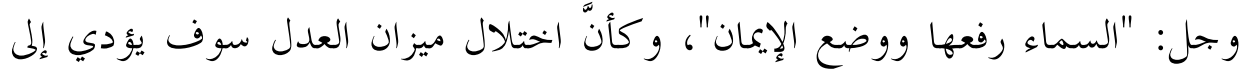
سقوط السماء من عليائها.

\section{ت. العدل مطلوب دائماً: - ت}

أرسى الله سبحانه وتعالى قاعدة إقامة العدل، وتحريم الظلم مبتدئًاً بنفسه، فقـــال:

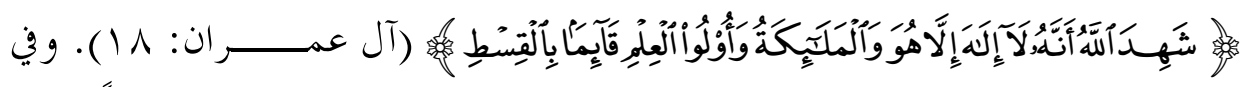

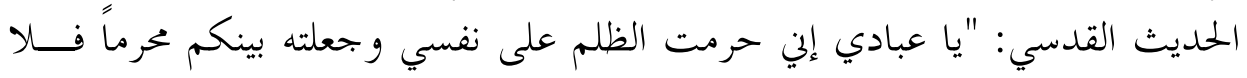

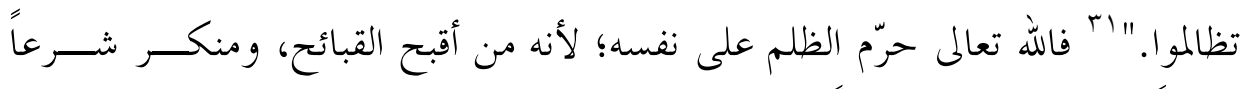

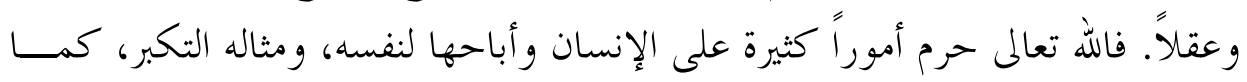

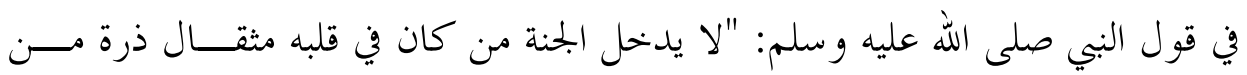

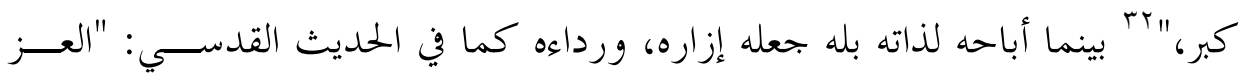

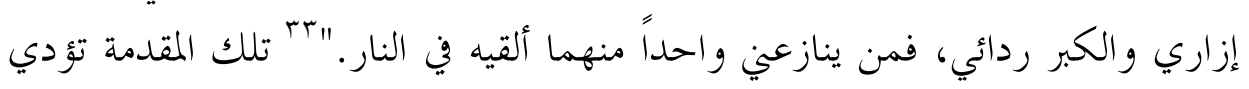

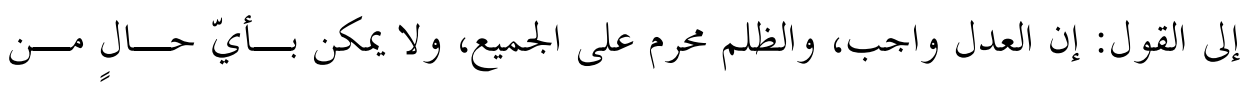
الأحوال التغاضي عن هذه الحقيقة.

وقد حرَّم الله عزَّ وجلَّ الظلم على الإنسان في جميع علاقاته، ابتداء بعلاقته بربِّــه:

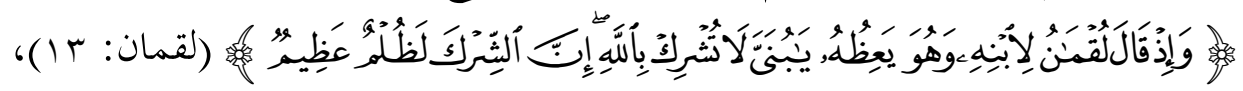

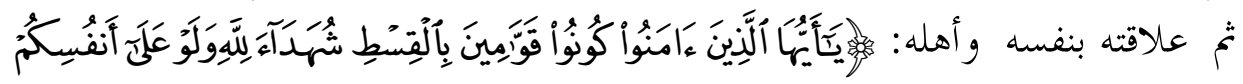

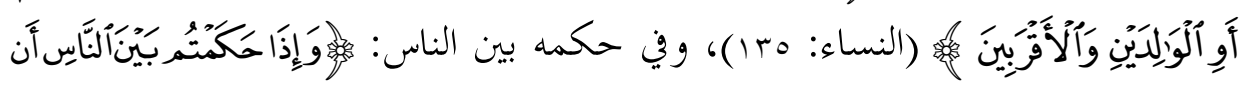

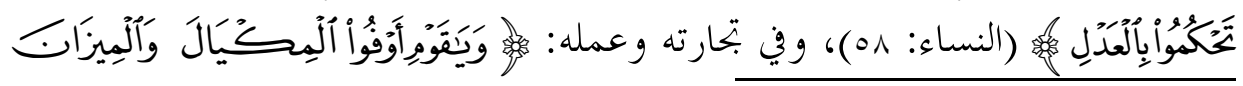

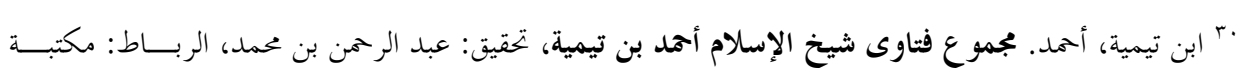

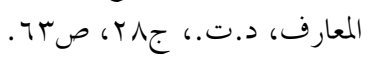

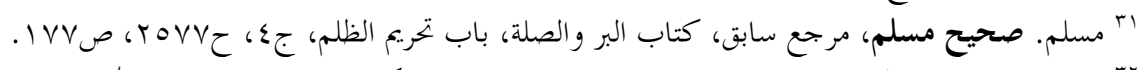

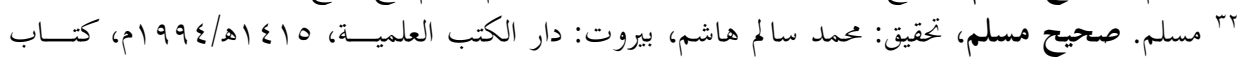

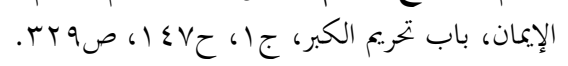

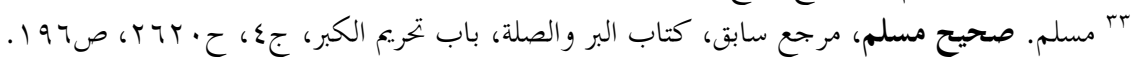




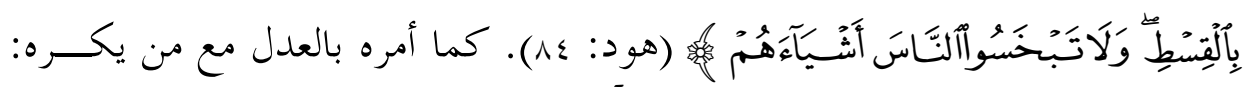

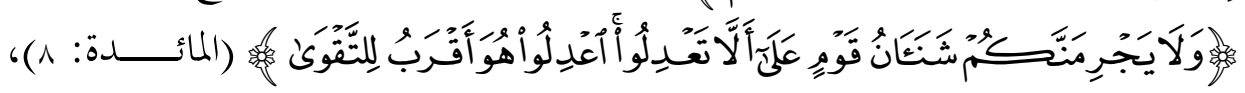

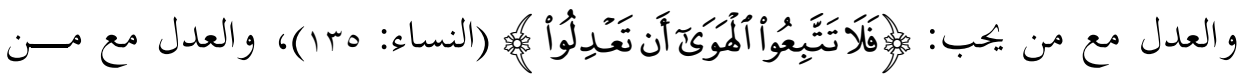

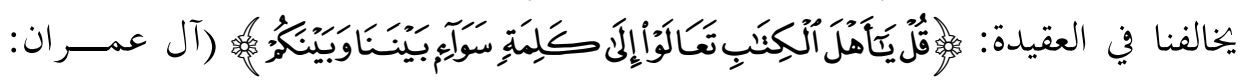

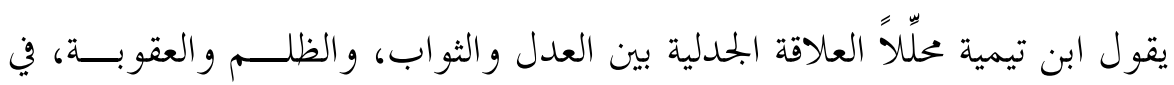

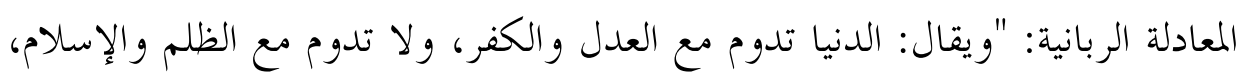

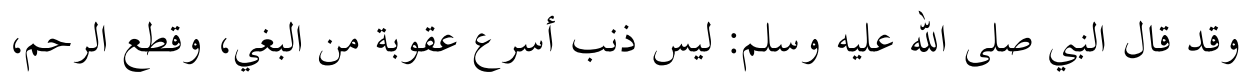

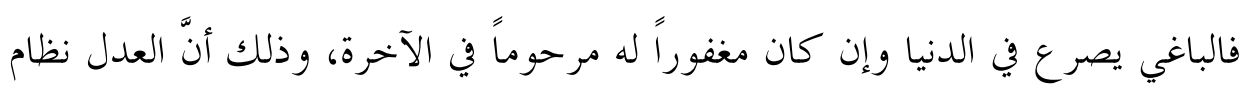

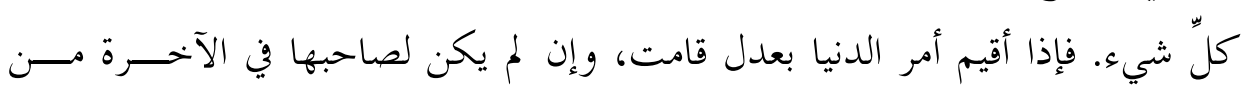

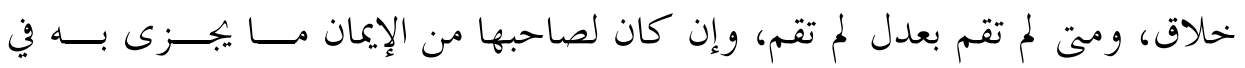

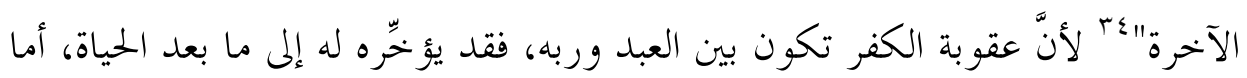

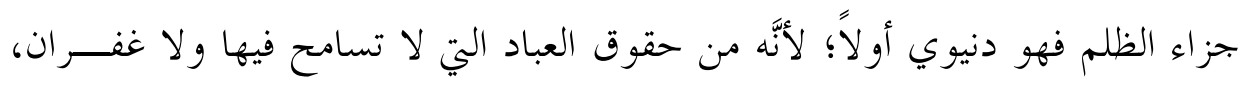

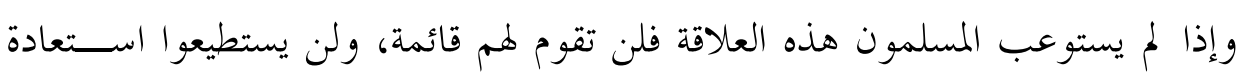

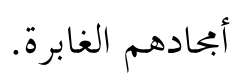

\section{r ا ـ انتماء العدل إلى منظومة الضروريات:}

أراد المتقدمون عند تحديدهم الضروريات إثباتا عن طريق التعبير عن كوها بدهية

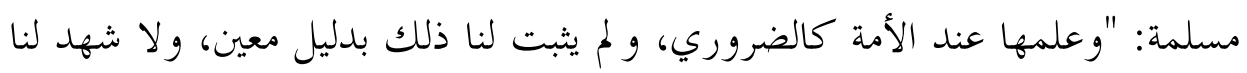

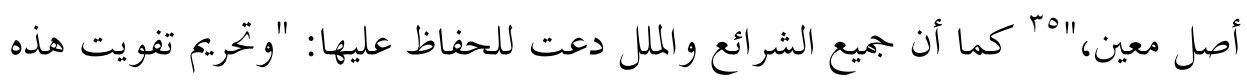

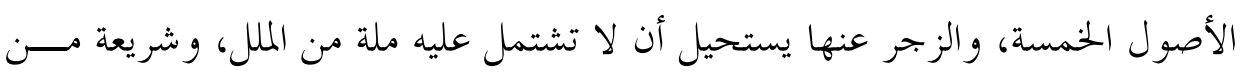

10

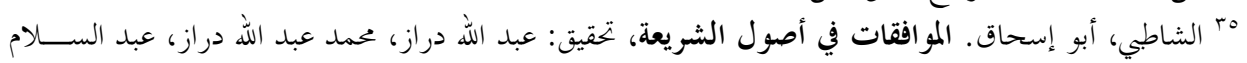

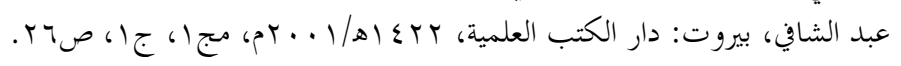




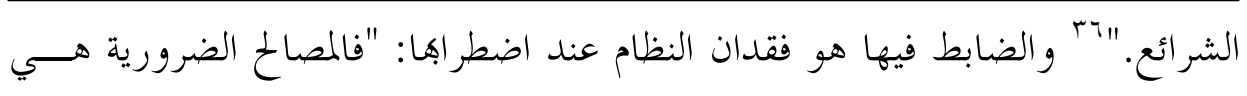
التي تكون الأمة بكجموعها، و آحادها في ضرورة إلى تحصيلها، بحيث لا يستقيم النظام

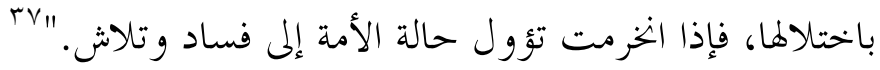

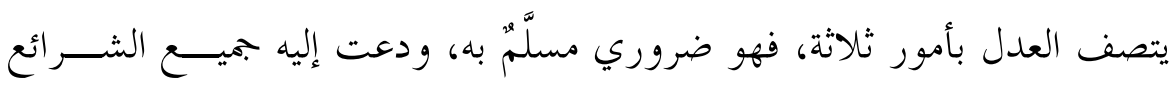

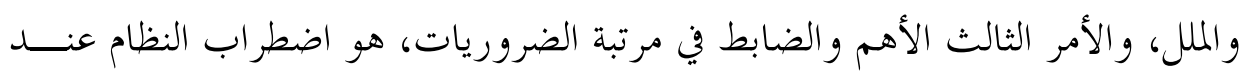

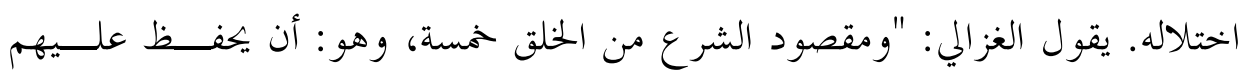

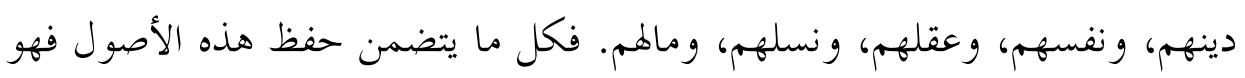

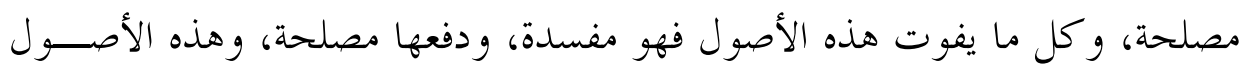

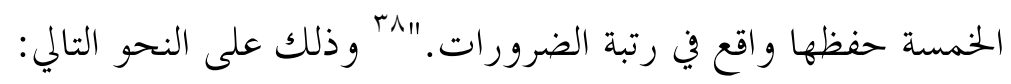

\section{أ. ترتب الضروريات على الأمر والنهي القطعي المتواتر:}

تواتر الأمر بالعدل، و النهي عن الظلم، كما ظهر في الآيات السابقة؛ إذ ورد ذكر

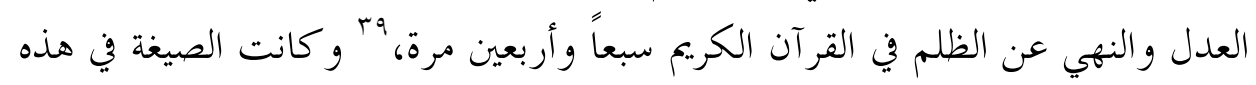

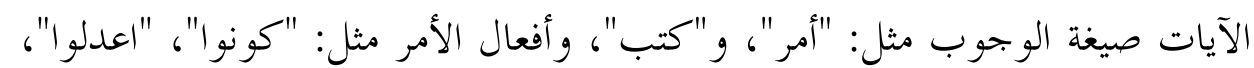

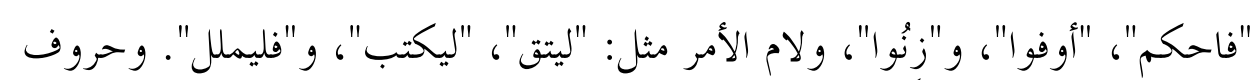

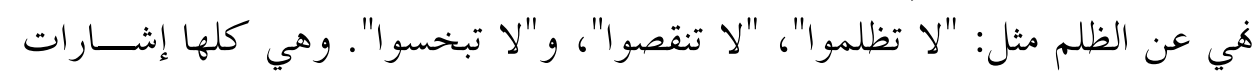

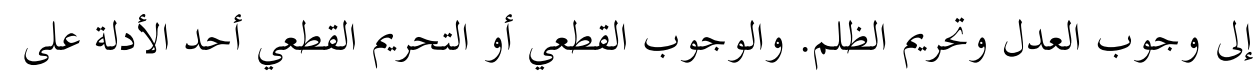

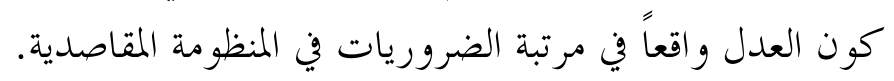

ب. توافق الضروريات مع المكافأة أو العقوبة المترتبة على الفعل أو الترك:

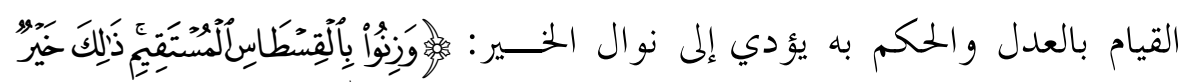

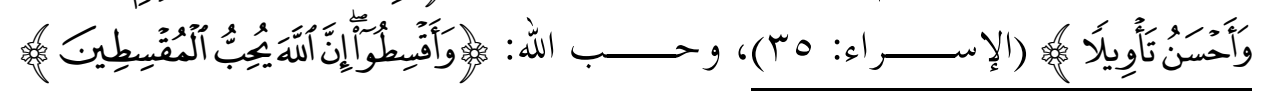

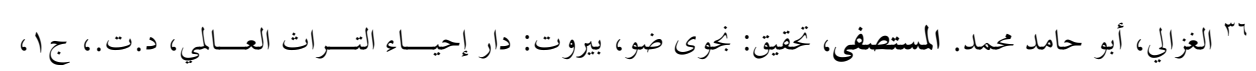
صד الب.

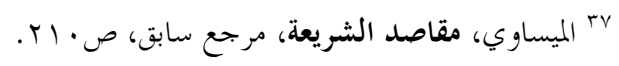

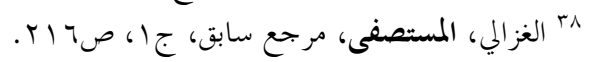

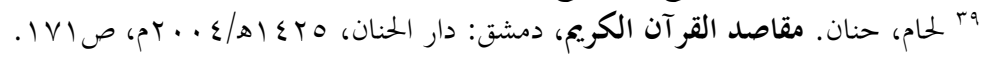




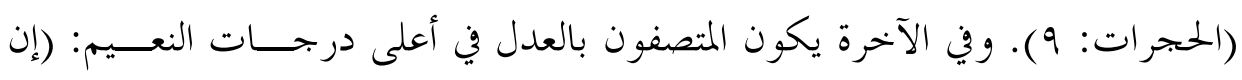

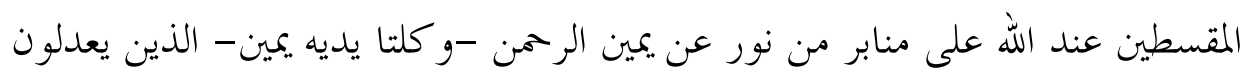

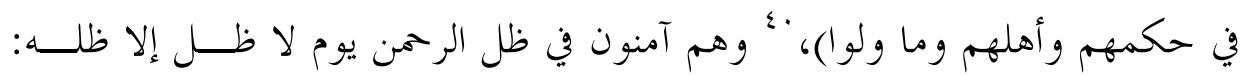

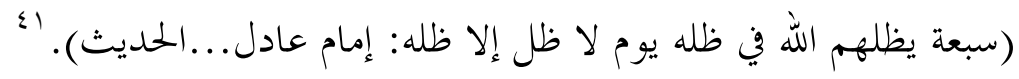

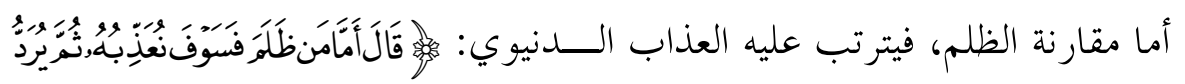

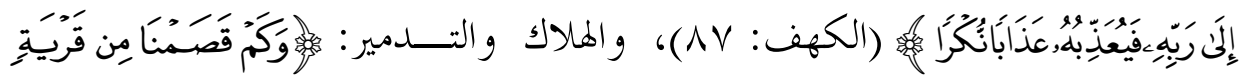

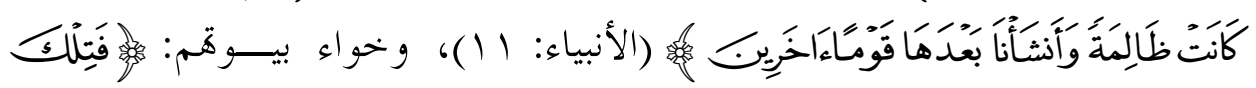

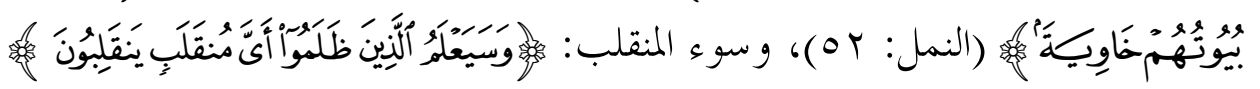

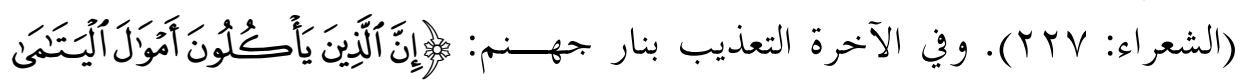

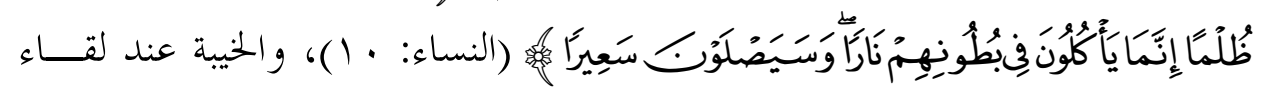

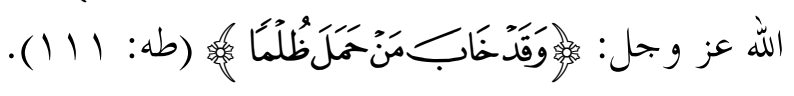

\section{ت. العدل مهيمن على الكليات الحمس:}

يمكن القول إنّه بإقامة العدل في علاقة الإنسان بربه، تتم رعاية مقصد الحفاظ على

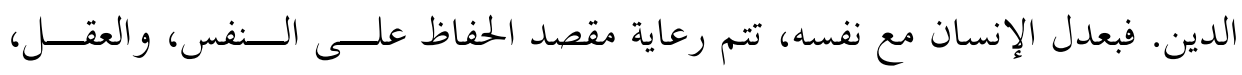

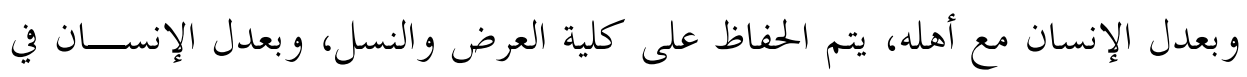
عمله، تتم رعاية مقصد الحفاظ على المال، وبعدل الإنسان في قضائه، تتم رعاية مقصد الحفاظ على الدين، و النفس، و المال.

فمقصد إقامة العدل مهيمن على الضروريات الخمس وحاكم عليها؛ لأنه مطلوب في كل علاقات الإنسان؛ مع نفسه، ومع غيره، وفي علاقاته المالية، وفي علاقاته بأهله،

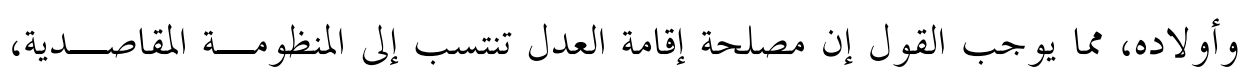
وتحتل مكانتها في مرتبة الضروريات.

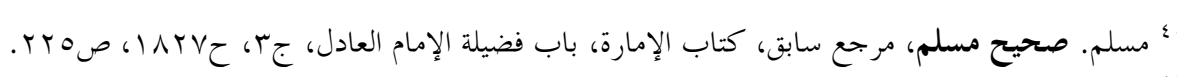

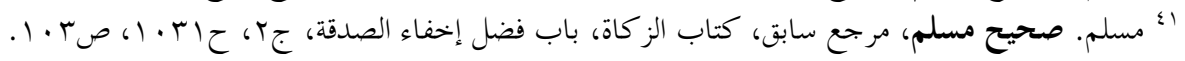




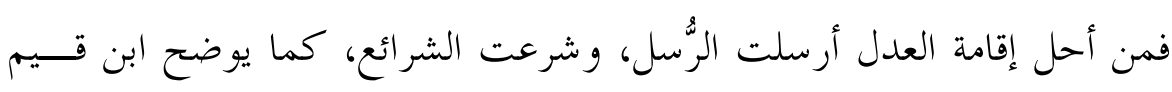

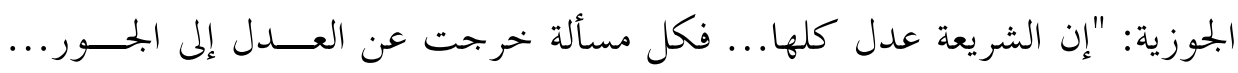

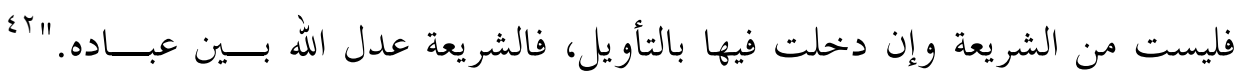

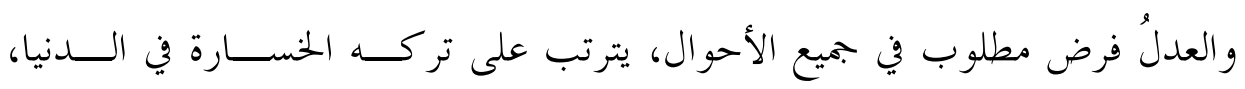

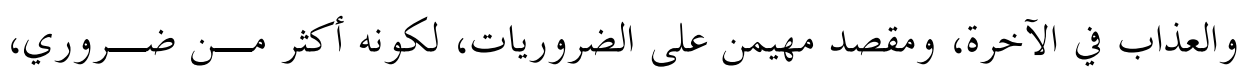

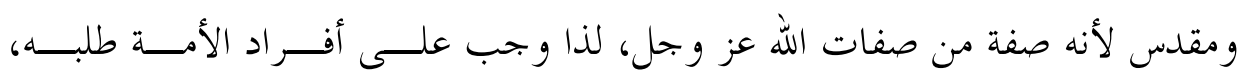

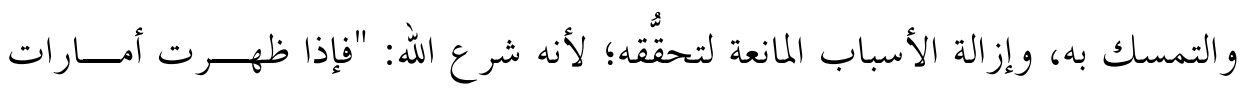

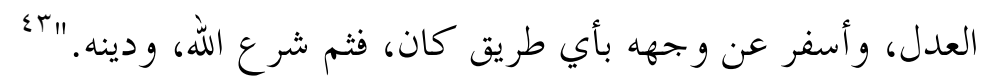

ثالثاً: الآراء الفقهية المختلفة في حكم تولي المرأة منصب القضاء عند النظر في آراء الفقهاء في تولي المرأة منصب القضاء بندها في أربعة ابتحاهــات

ا. الرأي الأول: عدم جواز تولي المرأة منصب القضاء:

وهو رأي الجمههور والحنابلة على الإطلاق، والشافعية باستثناء من قال بالضرورة، والمالكية باستثناء ابن القاسم، ورواية عن مالك.

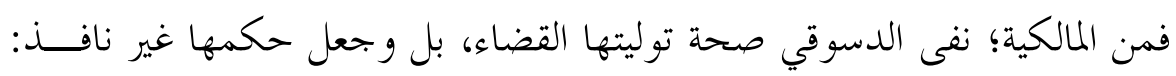

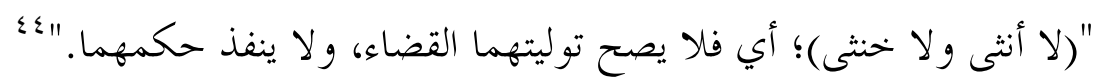

ومن الشافعية يقول الهيتمي: "(ذكر) فلا تولى امرأة، ولو فيما تقبل فيه شهادها،

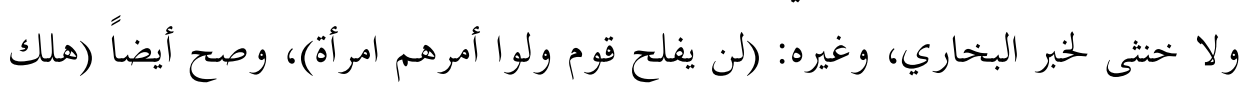

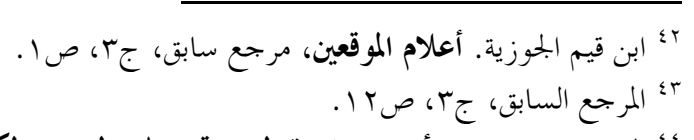

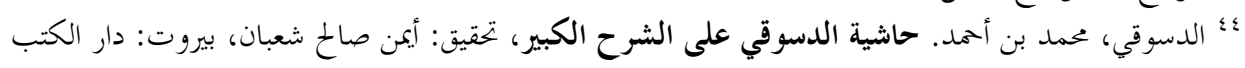

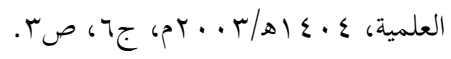




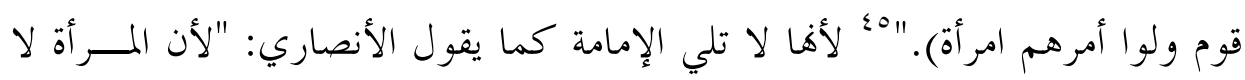

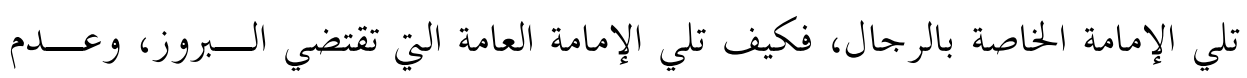

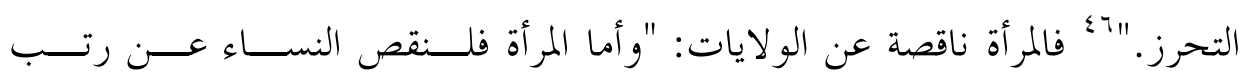

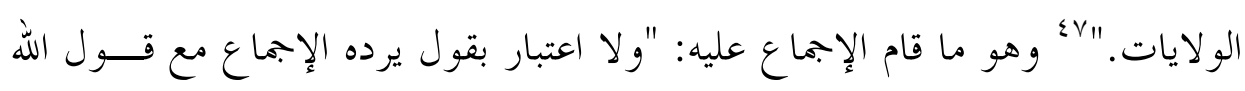

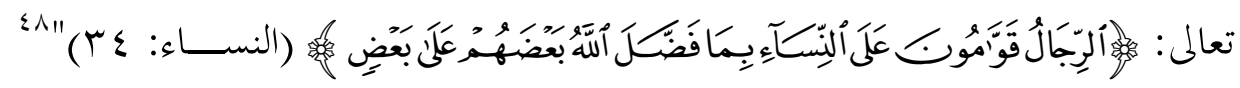

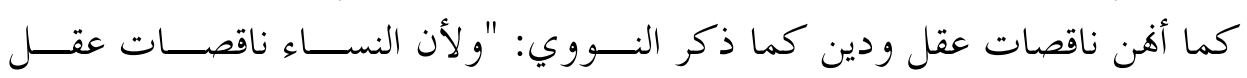
ودين.

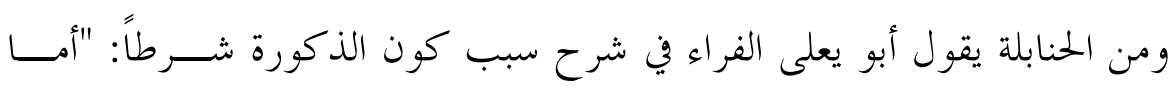

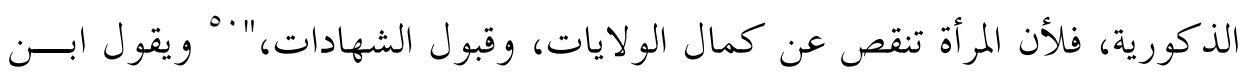

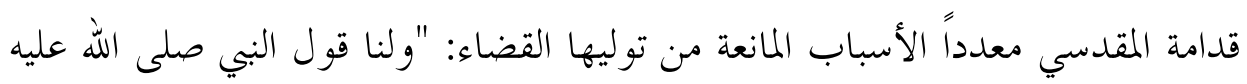

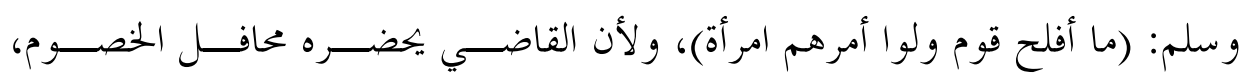

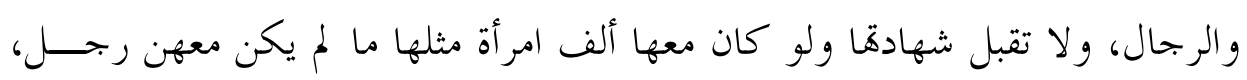

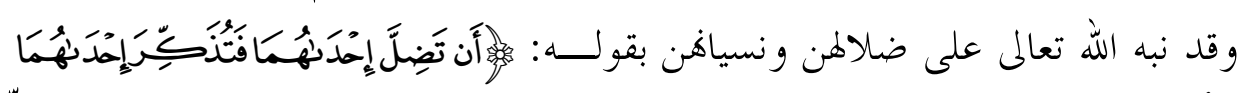

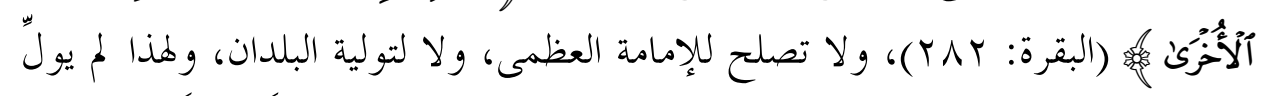

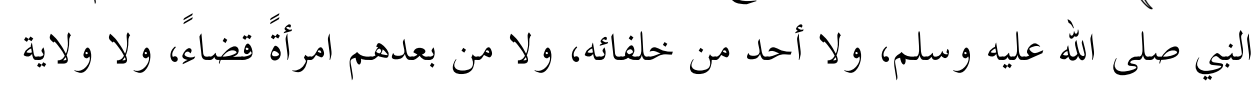

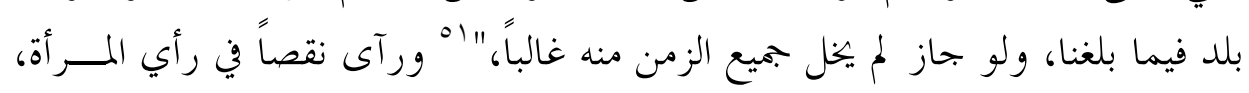

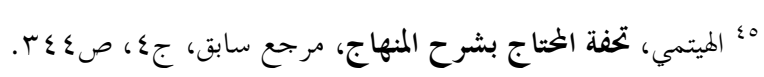

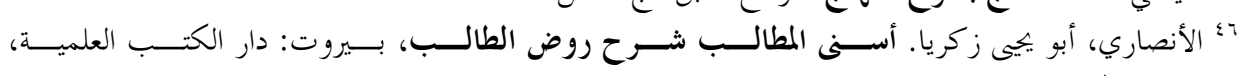

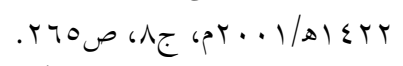
Vاء الماوردي، أبو الحسن علي. الأحكام السلطانية، تحقيق: عصام فارس الحرستاني، عمدا إبراهيم الزغلي، بيروت:

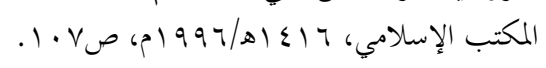

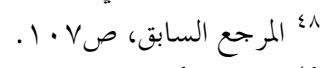

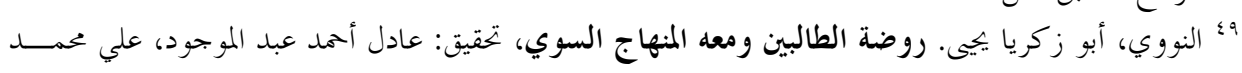

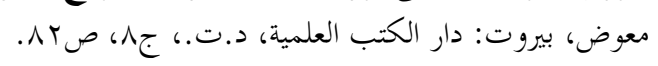
• ألفراء، أبو يعلى عمد بن الحسين. الأحكام السلطانية، تحقيق: حمد حامد الفقي، بيروت: دار الكتب العلمية،

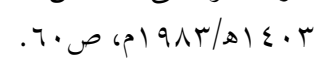

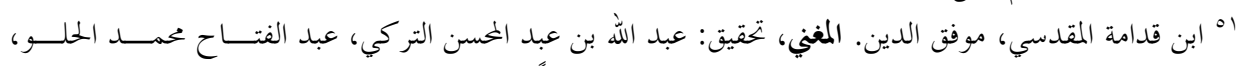

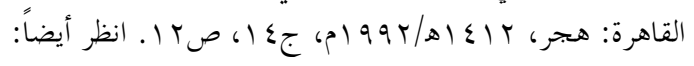




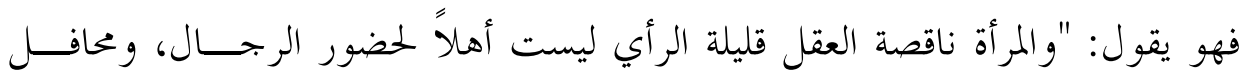

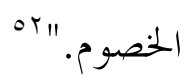

\section{r r جواز توليها القضاء للضرورة عند عدم وجود قاضٍ:}

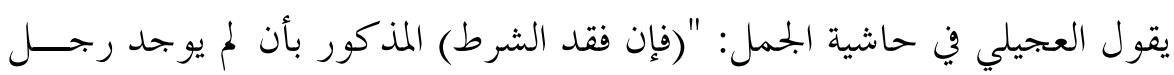

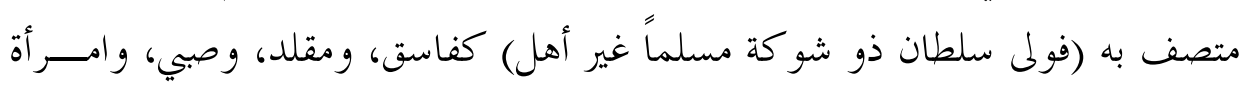

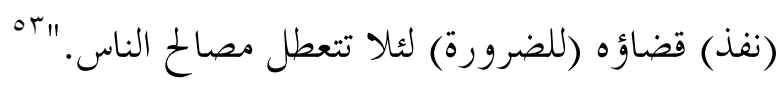

\section{r. جواز توليها القضاء فيما تجوز شهادقا فيه:}

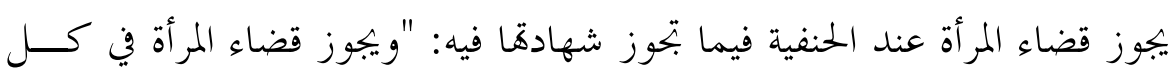

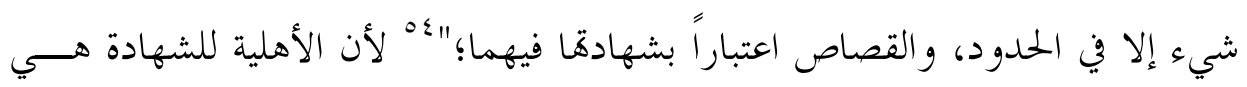

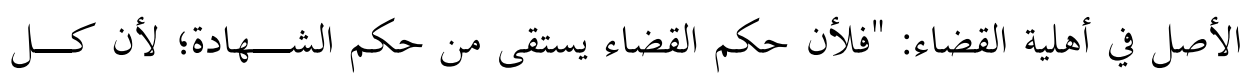

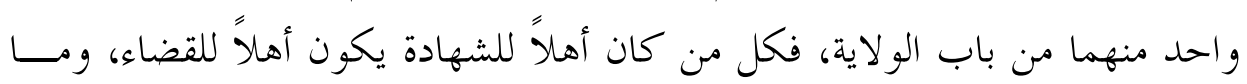

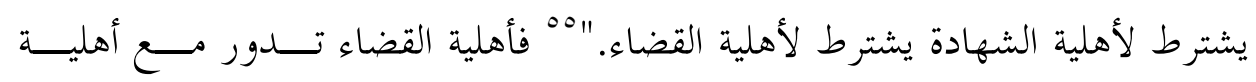

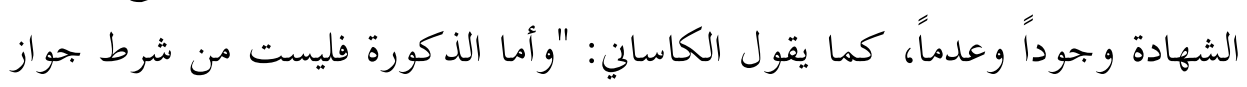

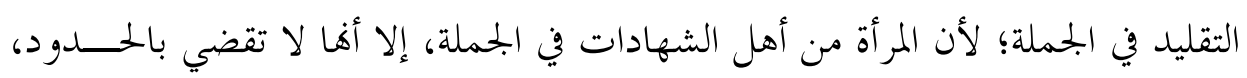

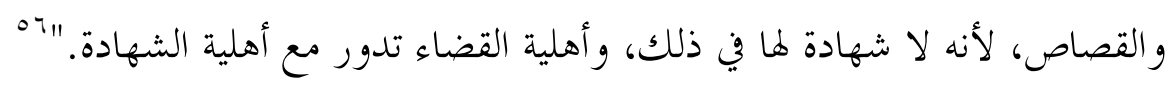

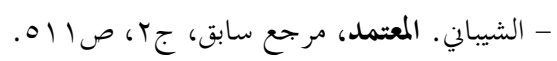
ror

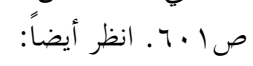

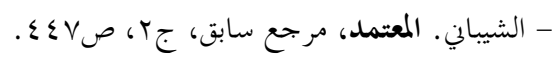

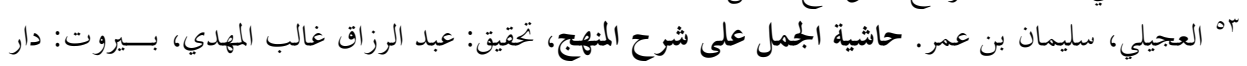

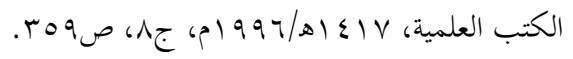

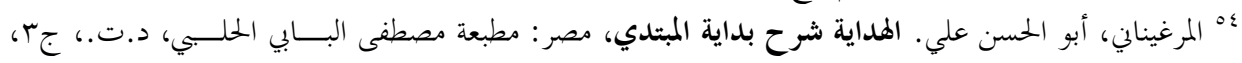

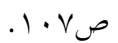

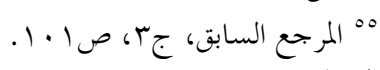

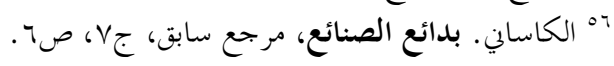




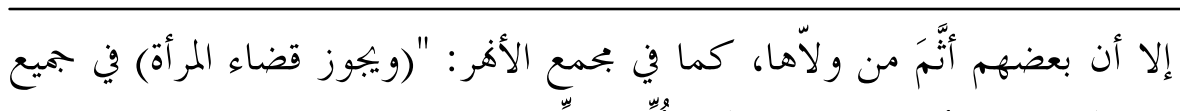

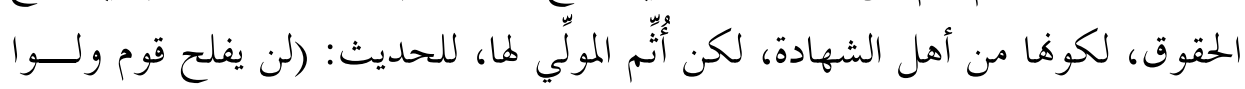

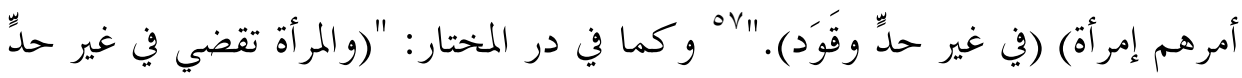

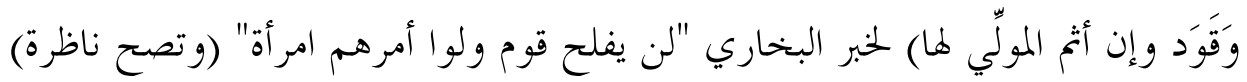

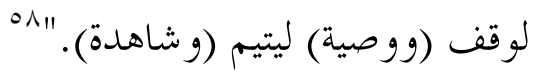

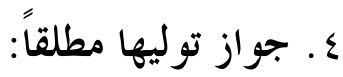

وردت عدة روايات بجواز قضاء المرأة عند بعض المالكية، ففي مواهب الجليـل:

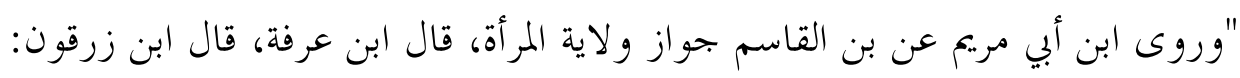

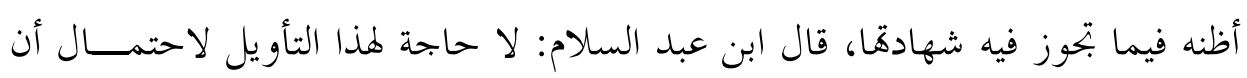

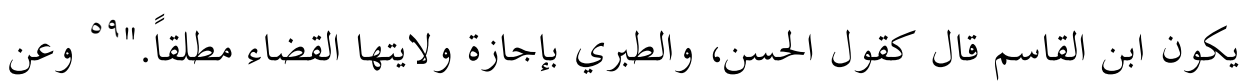

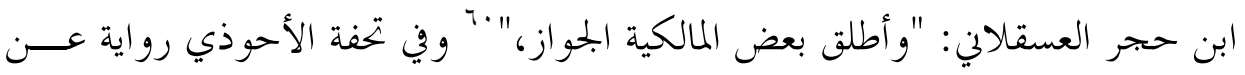

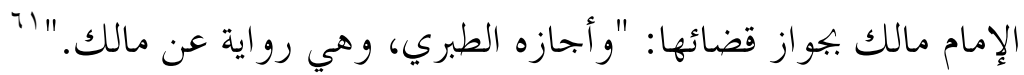

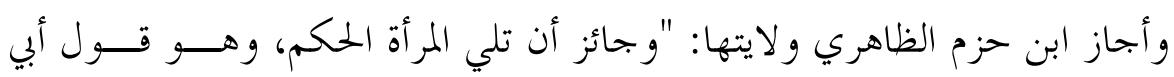

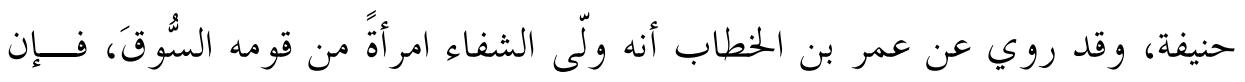

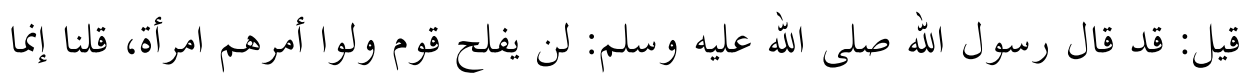

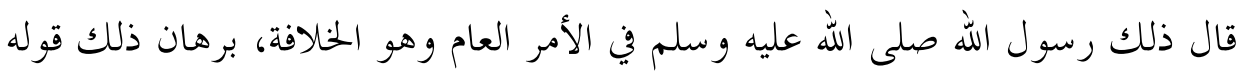

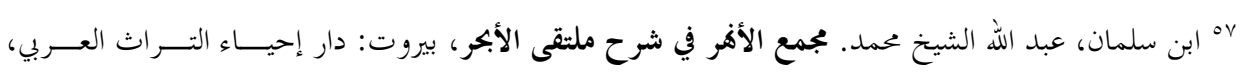

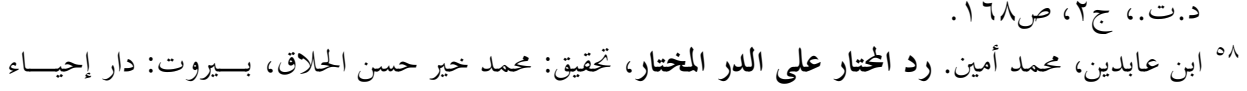

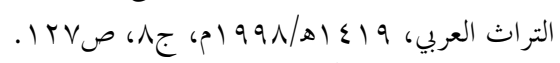

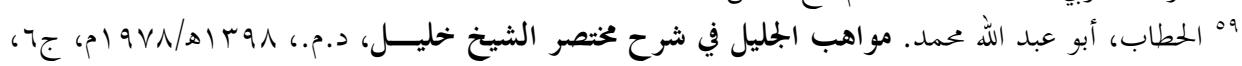

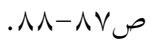

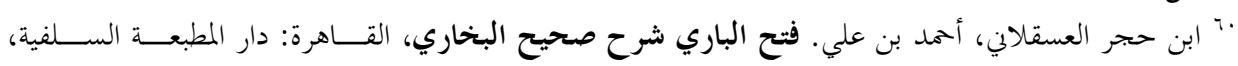
1)

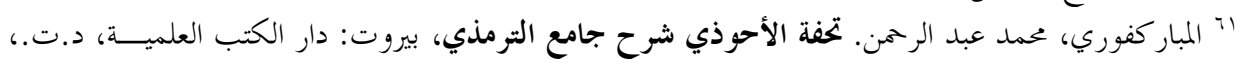

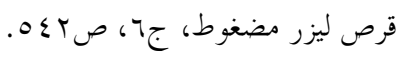




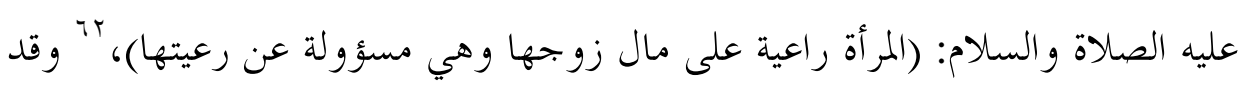

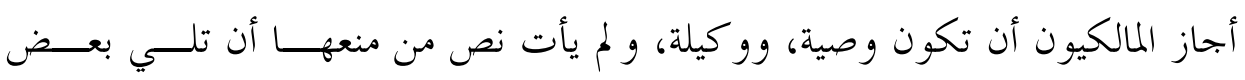

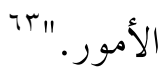

وأجاز الطبري قضاءها على الإطلاق، كما ورد في كتابه اختلاف الفقهاء: "وشذ فئ

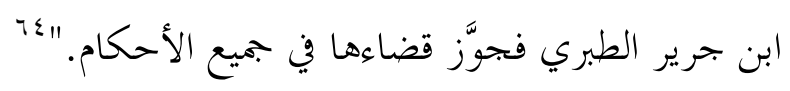

رابعاً: إشكاليات الأدلة الداعمة لحكم التحريم

\section{1 إشكاليات فهم النصوص المعتمد عليها:}

\section{أ. إشكالية الاستدلات بالحديث الخوري الخرِّم:}

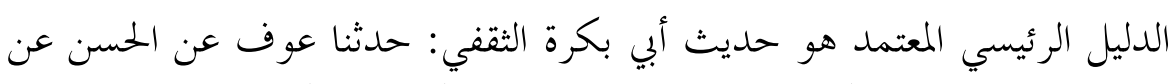

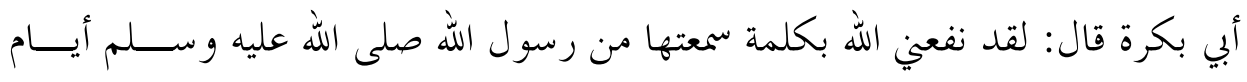

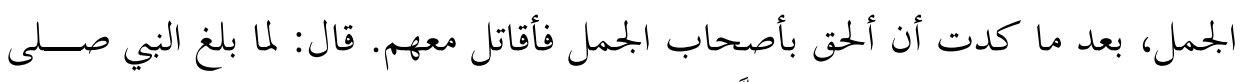

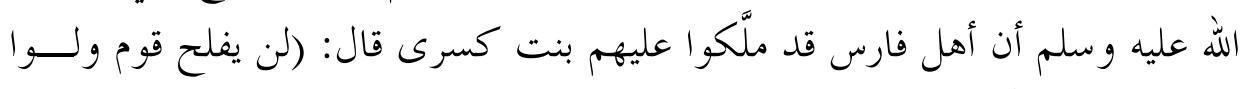
أمرهم امرأة).

وقد تعرّض هذا الدليل لانتقادات كثيرة من أصحاب وجههات النظر المجوّزة، لـــــا

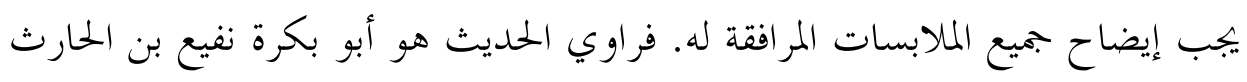

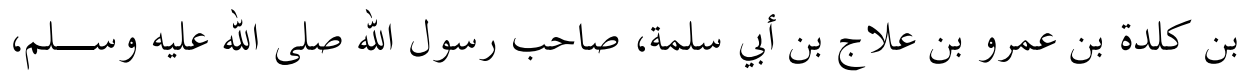

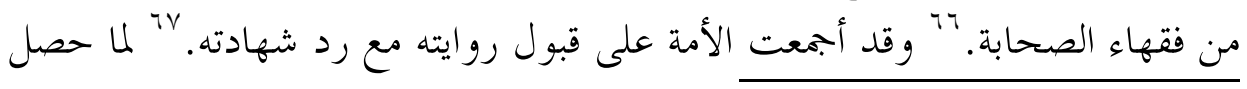

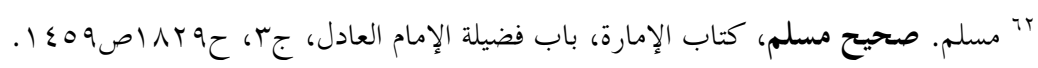

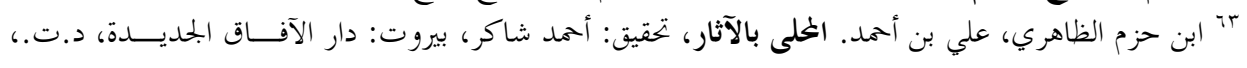

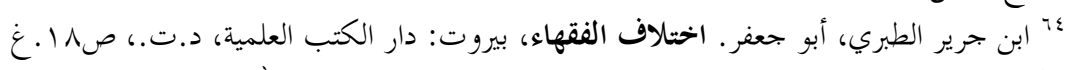

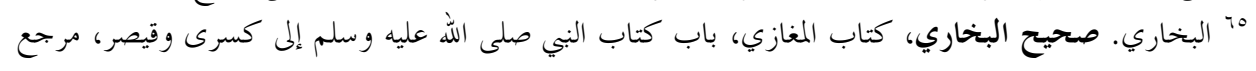

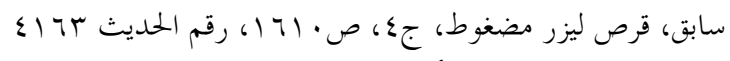

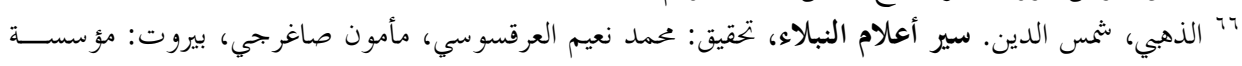

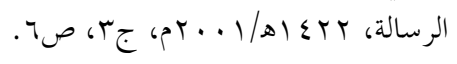




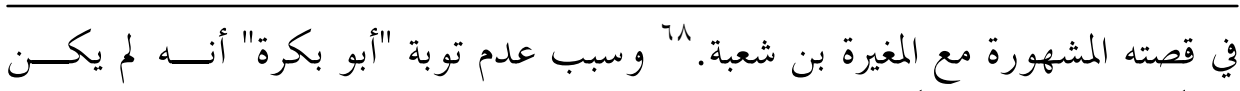
قاذفاً، و إنما كان شاهداً.

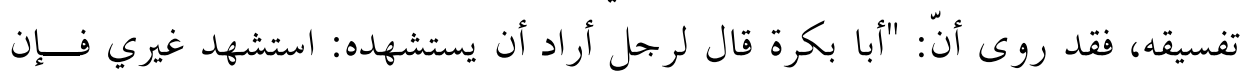

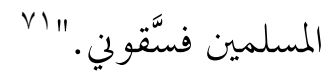

أمّا القضية الثانية المتّصلة براوي الحديث، فهي أن أبا بكرة تذكر الحمديث عنــــــا

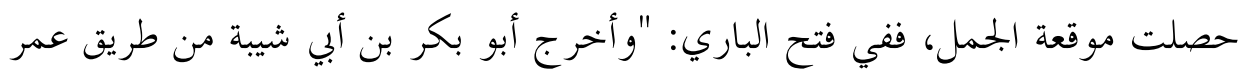

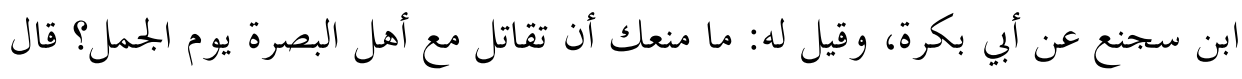

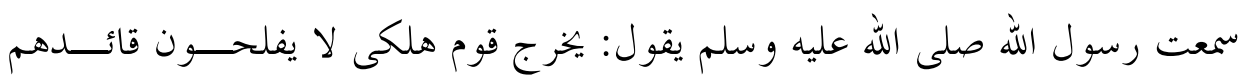

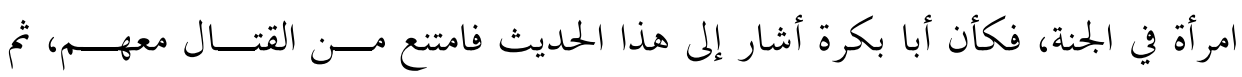

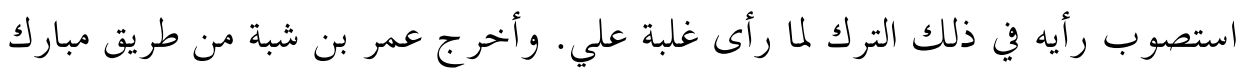

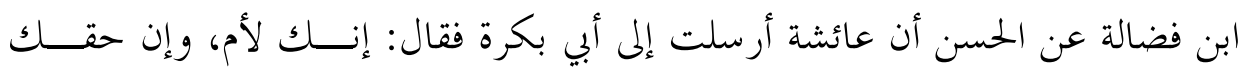

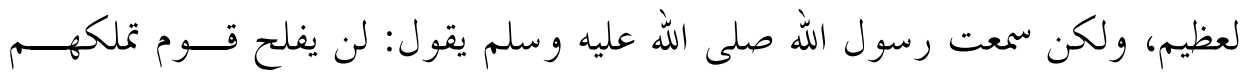

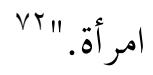

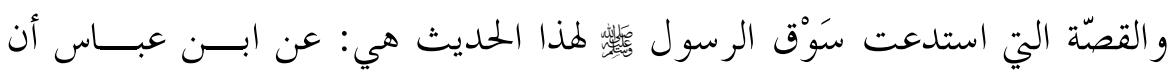

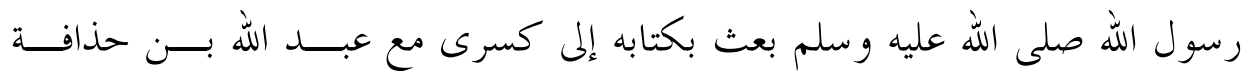

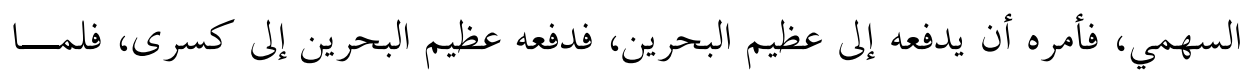

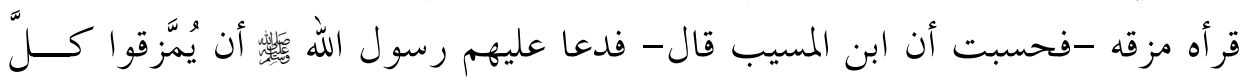

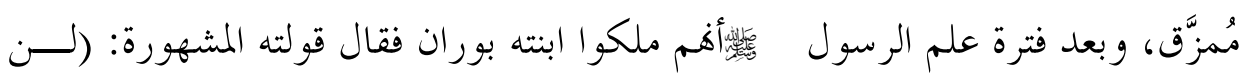

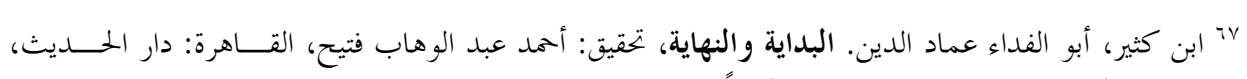

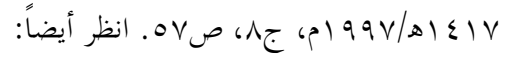

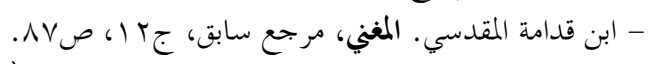

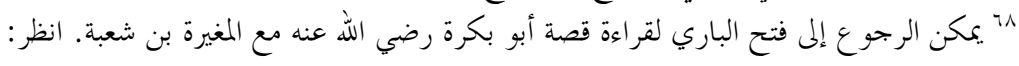

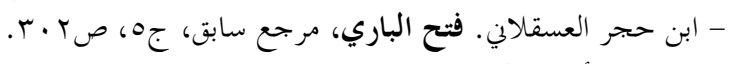

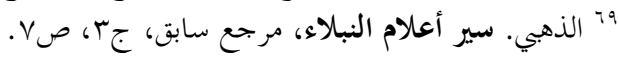

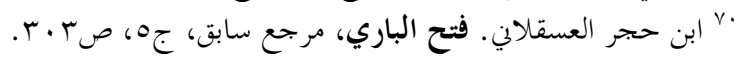

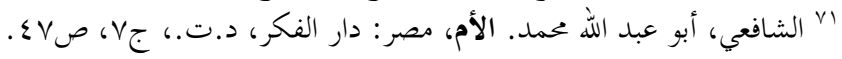

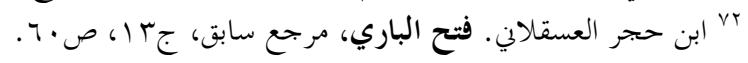




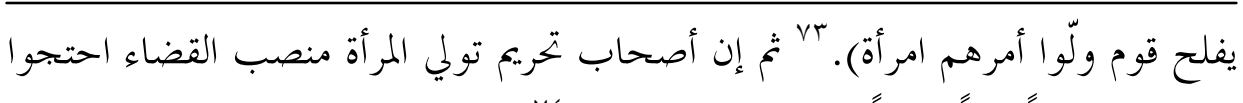

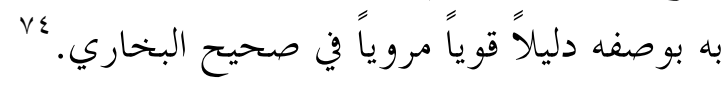

بالتدقيق في هذا الحديث وهو الدليل الأساسي الذي استند إليه من حرّم تولي المرأة

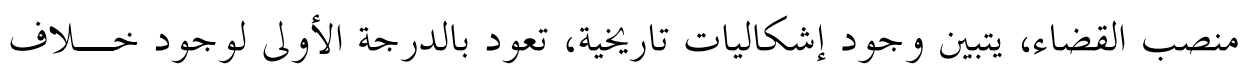
حول التاريخ الذي تمت فيه مراسلات النبي صلى الله عليه وسلم إلى الأمراء. ففريق يرى أن المراسلات كانت في السنة السابعة للهجرة، كما ورد عن الو اقدي:

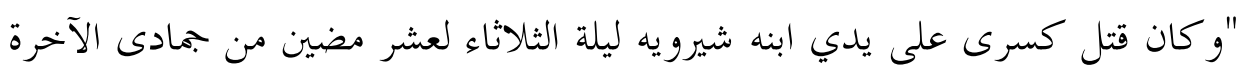

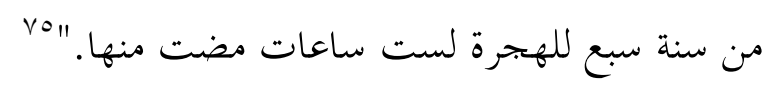

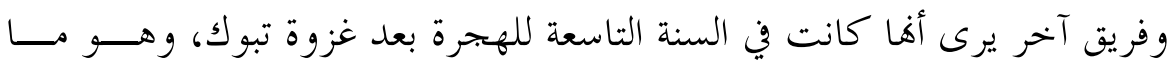

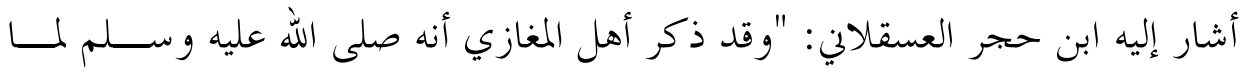

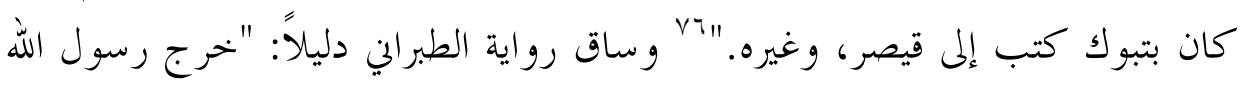

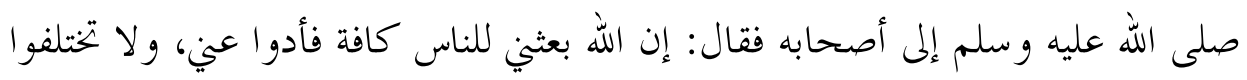

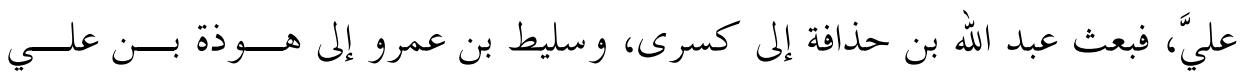

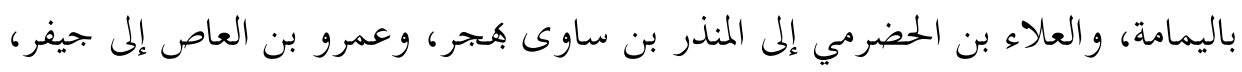

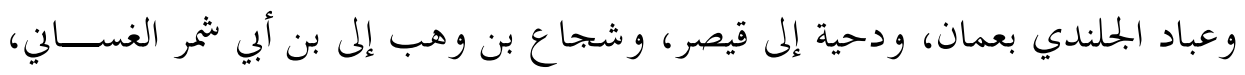

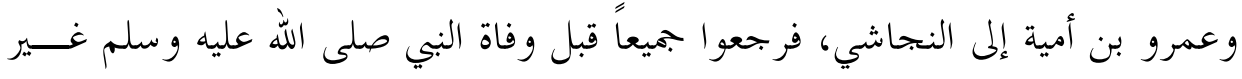

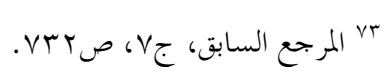

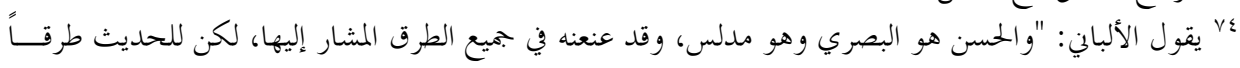

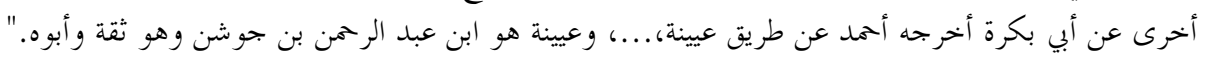
انظر: - الألباني، محمد ناصر الدين. إرواء الغليل في تخزيج أحاديث منار السبيل، بيروت: المكتــب الإسـادمي،

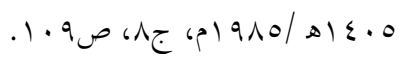

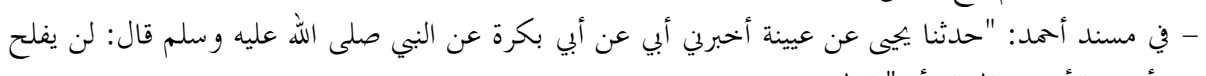

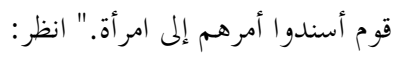

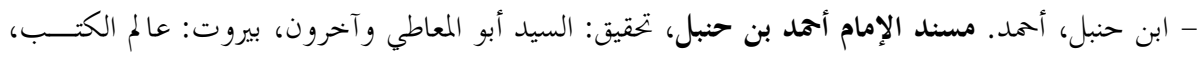

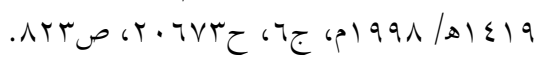

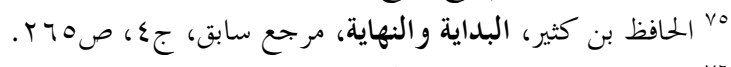

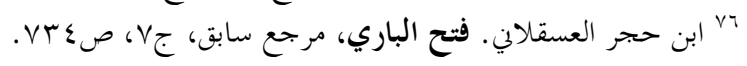




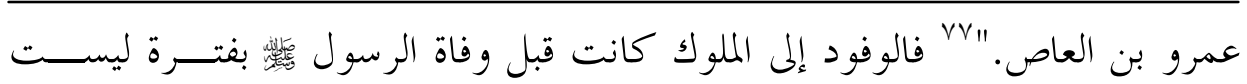
بطويلة، لأنه لا يمكن أن يستمر غياب عمرو بن العاص أكثر من ثلاث سنوات إت، فيما

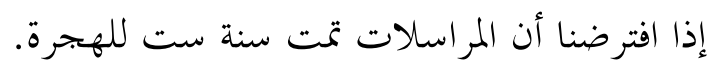

و ونقل ابن كثير عن السهيلي: "و كان قتله ليلة الثلاثاء لعشر خلون مـــن جمــادى

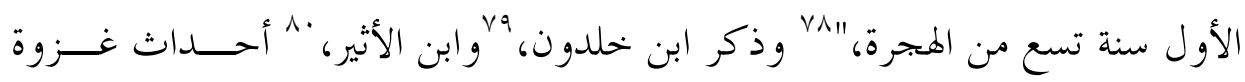

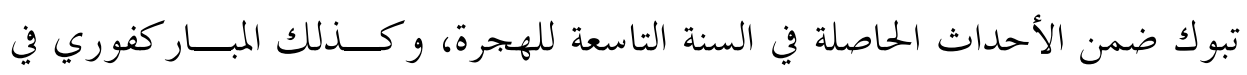

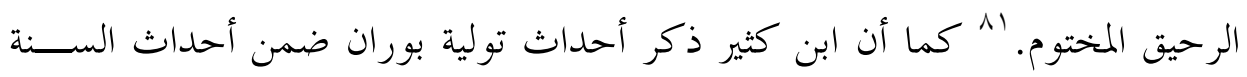
الثالثة عشرة للهجرة. الميق المتوم.

فإذا كانت مراسلة البي

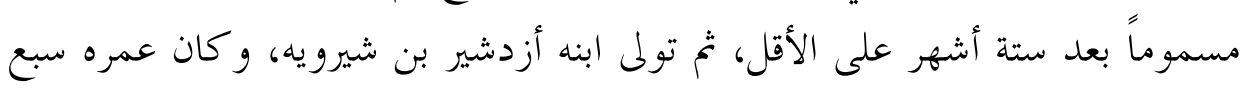

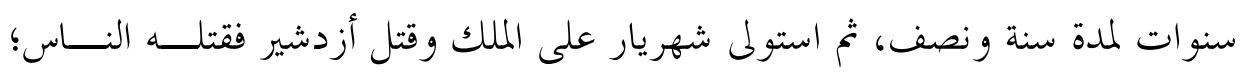

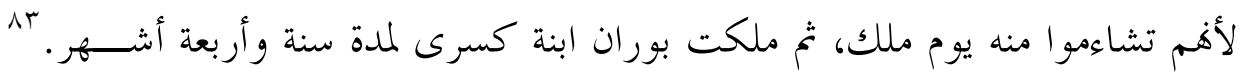
فكيف بلغ البي تمليكهم بوران وهو قد توفي سنة عشر للهجرة؟ وهذا يثبت أن الــنبي صلى الله عليه وسلم لم يسمع بتولية ابنة كسرى بوران مما يطعن في صحة الحميث.

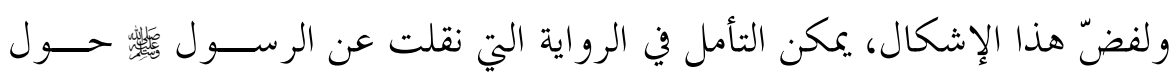
خروج عائشة رضي الله عنها عام الجمل: "يخرج قوم هلكى لا يفلحون، قائدهم امرأة

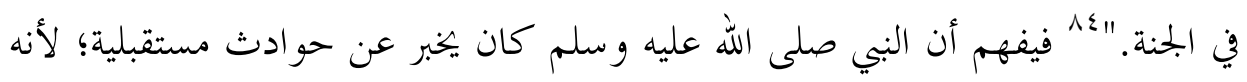

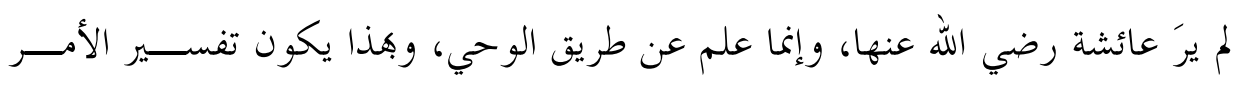

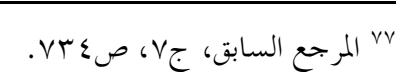

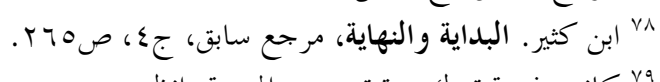

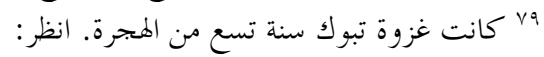

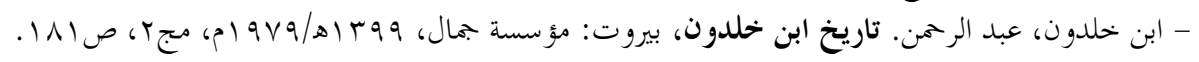

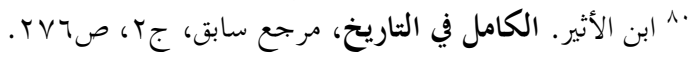

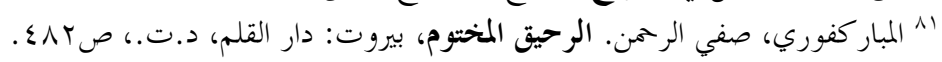

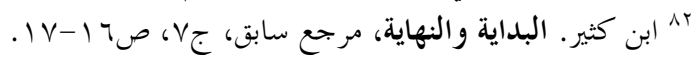

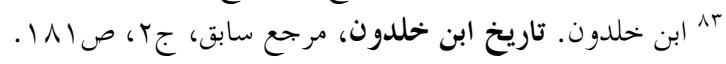

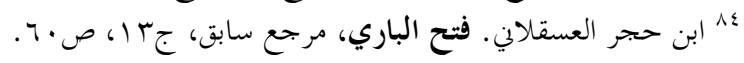


كالتالي: ستهلك الطائفة التي من أوصافها أها تقودها امرأة، هي السيدة عائشة رضي

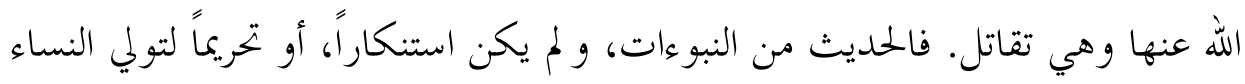

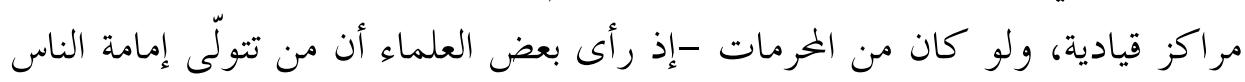
تستتاب هـ-ـ لعلمت هذذا السيدة عائشة رضي الله عنها، و لم تفعله. فصيغة هذه الرواية إخبارية، وليست إنشائية، ويقاس عليها حديث: لن يفلح قوم ولو أمرهم امرأة.

\section{ب. إشكالية الاستدلال بالآيات القر آنية:}

استدل المانعون لتولي المرأة منصب القضاء بعدة آيات، إلا أن البحث يثبت عـــدم مناسبتها لموضع الاستدلال، مثل قوله تعالى:

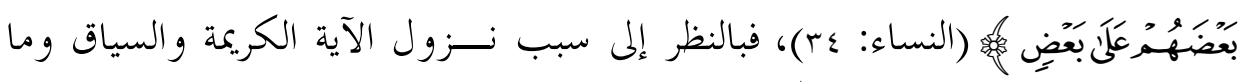

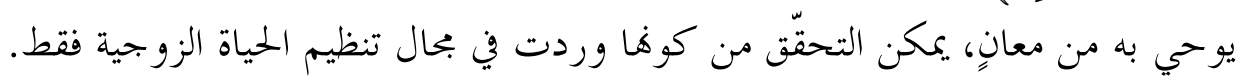

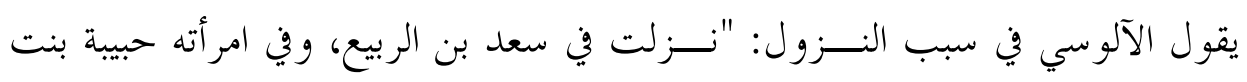

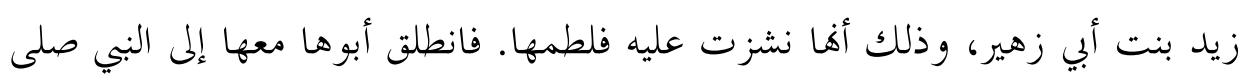

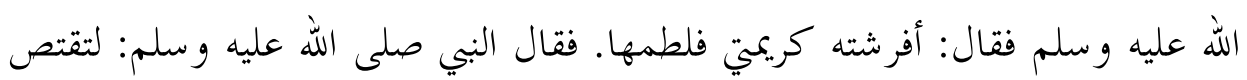

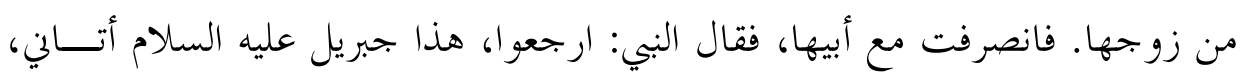

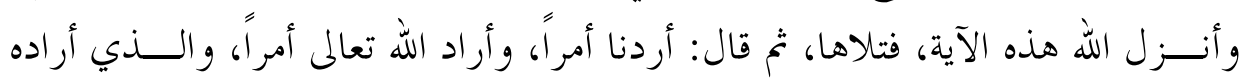

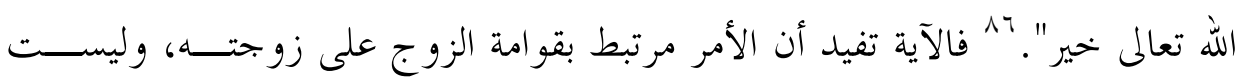
قو امة كل رجل على كل امرأة، فهذا محال. كما أن الطبري أورد شرح الآية في بجال الأسرة، و لم يتطرق إلى أمسـور أخـــىى

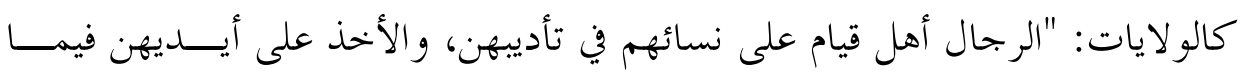
هي يقول ابن عابدين: "و أما تقريرها في نحو وظيفة الإمام فلا شك في عدم صحته لعدم أهليتها خلافاً لما زعمه بعض ألها

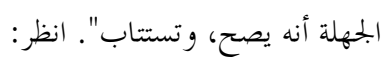

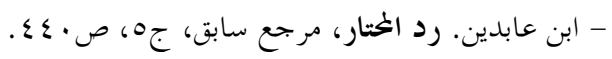

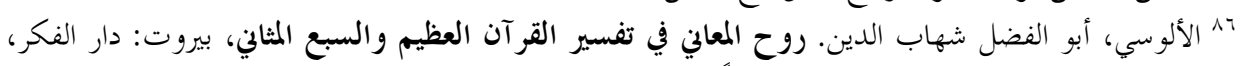

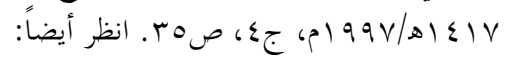

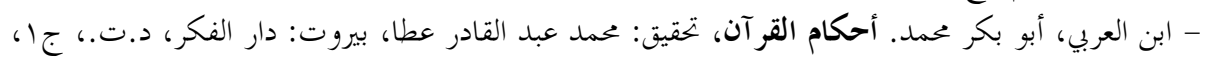




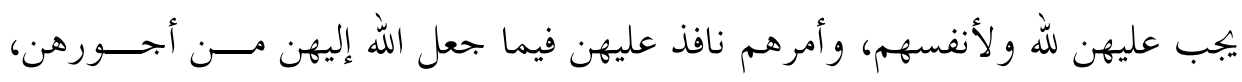

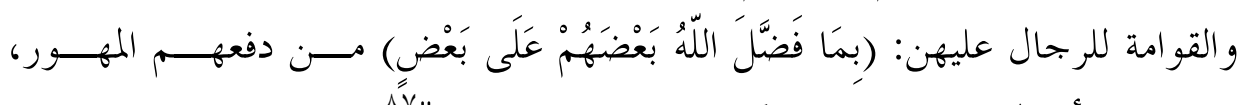

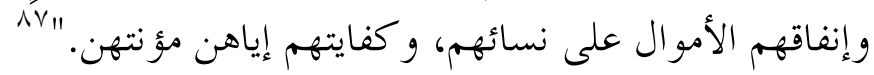

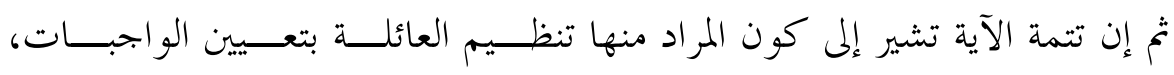

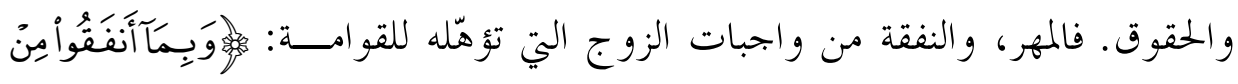

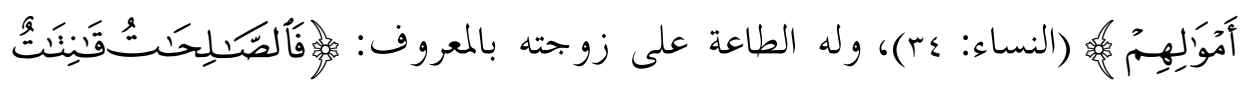

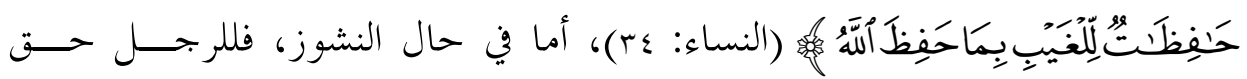

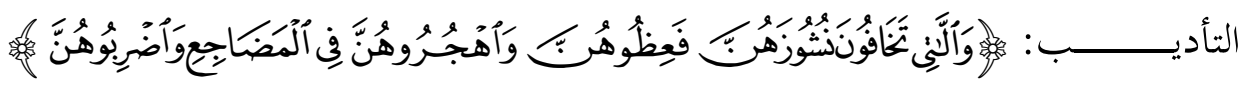
(النساء: §r)، فالموضع هنا تنظيم الأسرة في القانون الإسالامي، وليس تنظيم الدولة في القانون السياسي.

وكذلك القول في الآية الكريمة التي استشهد هـا المانعون، و جعلوها سبب قــوهم

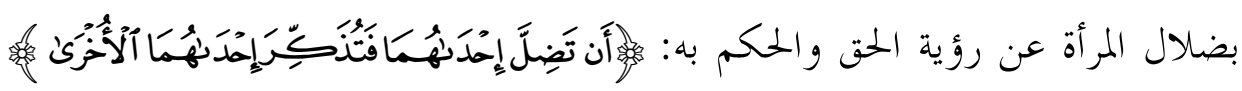

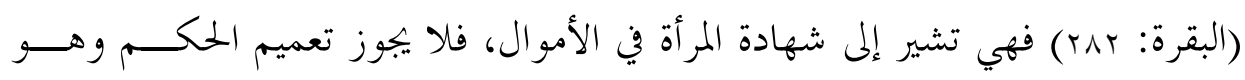

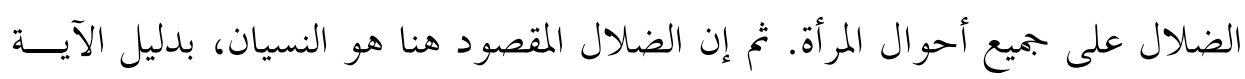

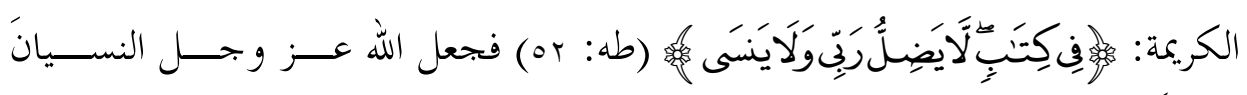

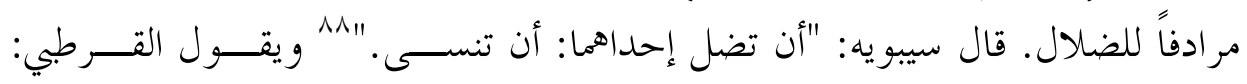

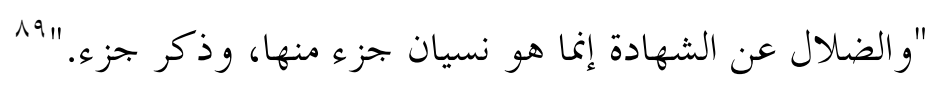

فلو كانت المرأة ضالة لما اهتدت آسية زوجة فرعون بالله إلى الحق، حتى استحقت

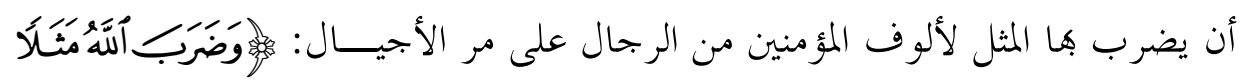

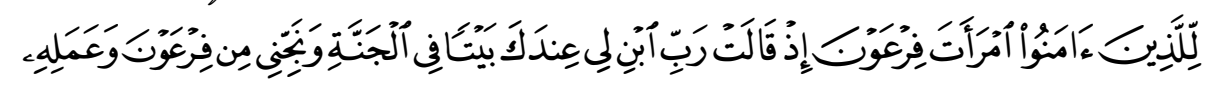

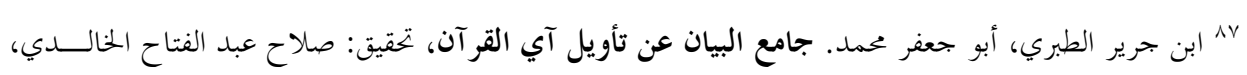

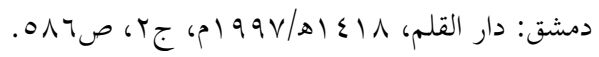

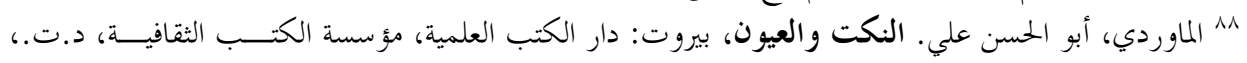

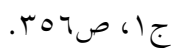

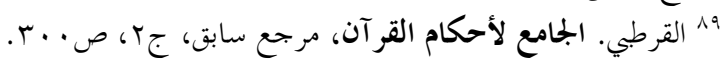




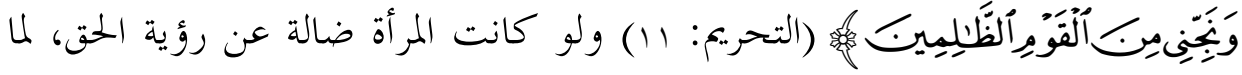

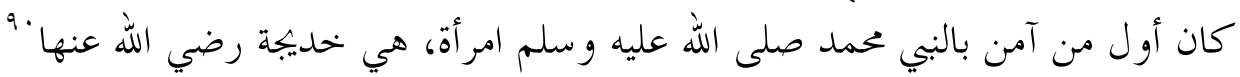

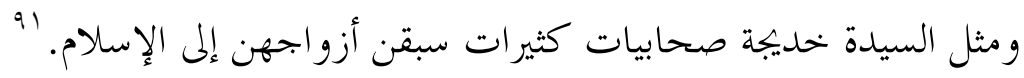

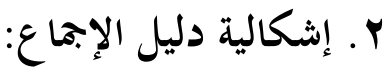

تبدو إشكالية الإجماع في إنكار وقوعه من بجموعة معتبرة من العلماء، والمثال عليه

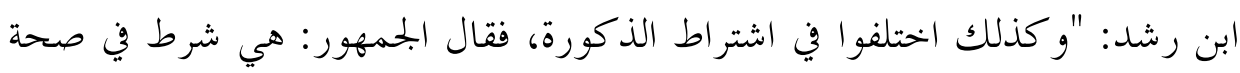

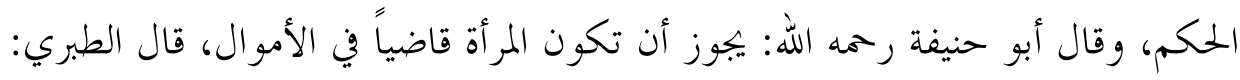

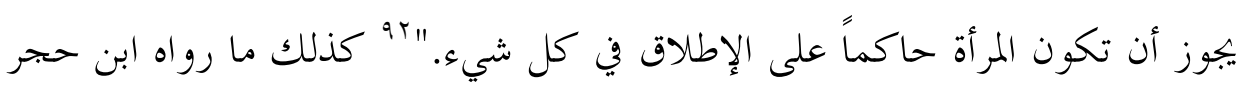

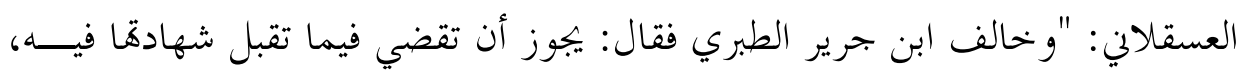

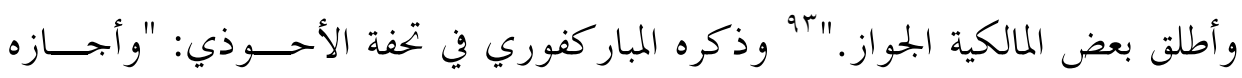

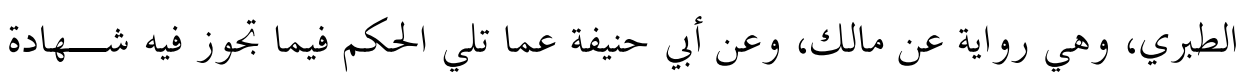
النساء." أو الن

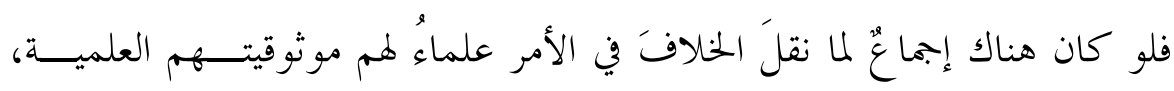

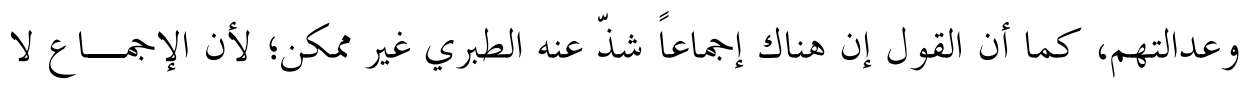

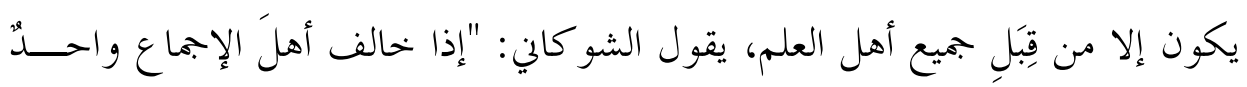

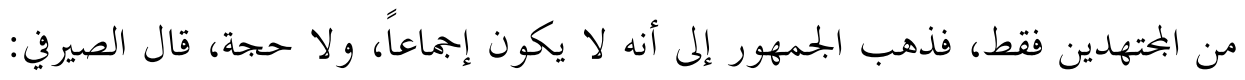

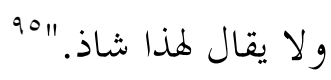

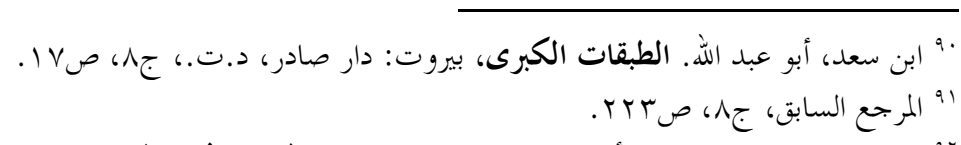

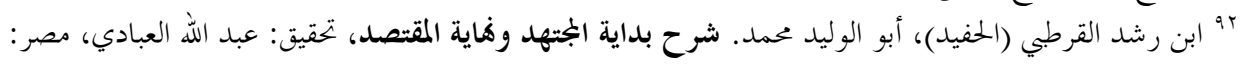

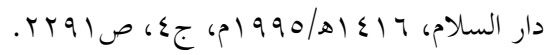

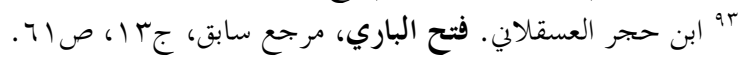

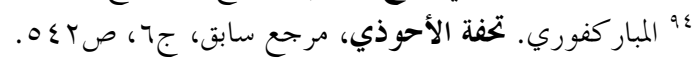

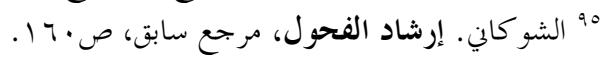


كما أن أصحاب الرأي القائل بحرمة تولي المرأة منصب القضاء استعانوا بكــــون

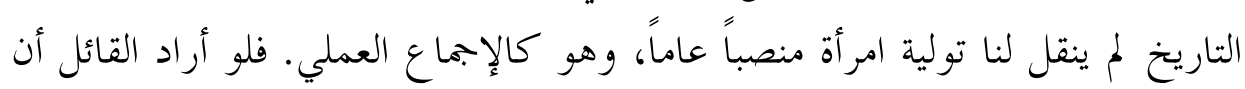

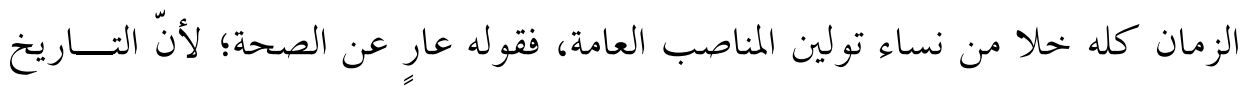

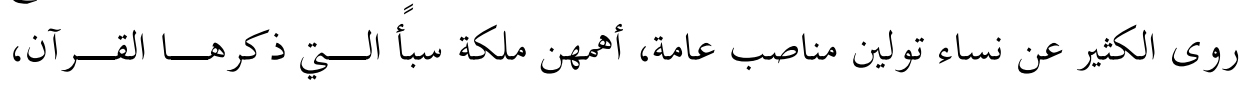

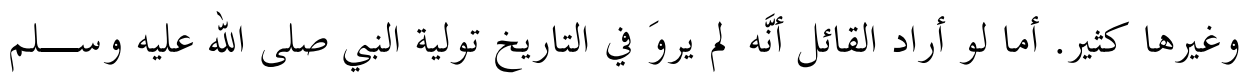

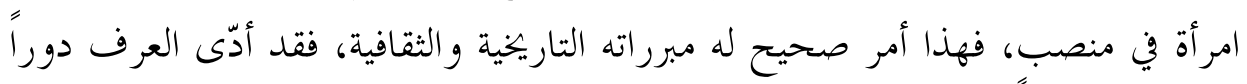
رئيسياً في عدم تولي المرأة منصب القضاء فئر عند العرب في الجاهلية، ووي صدر الإسلام.

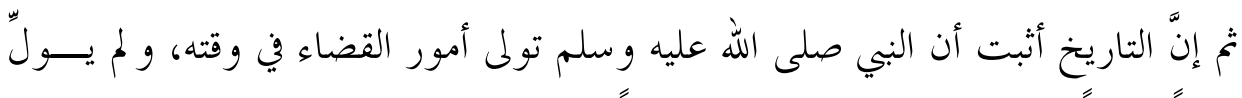

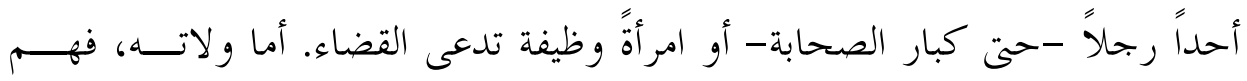

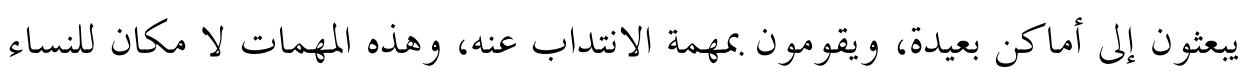
فيها، ومع ذلك فقد حدث وأن تولت بعض النساء بعض الأمور مثل سمر اء بنت فيك

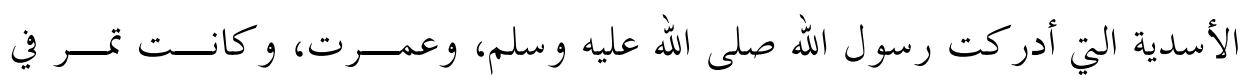

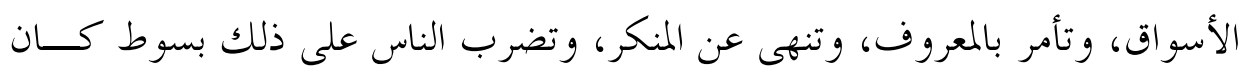
97 .

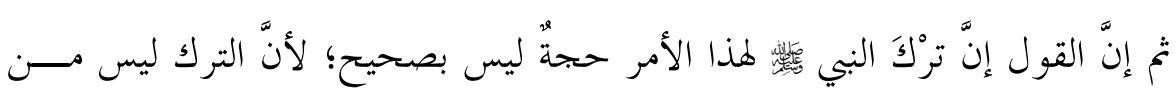

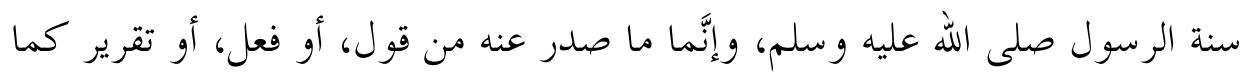

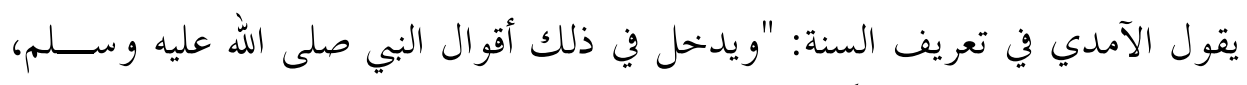

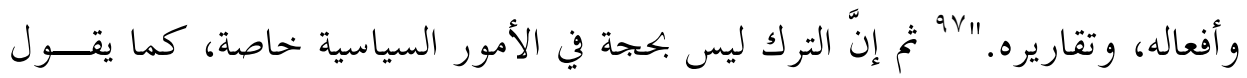

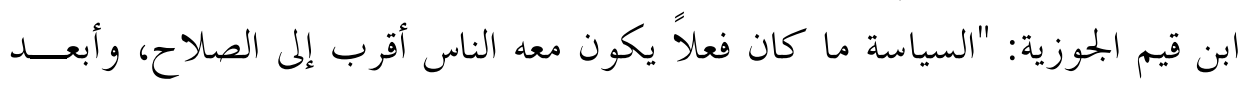

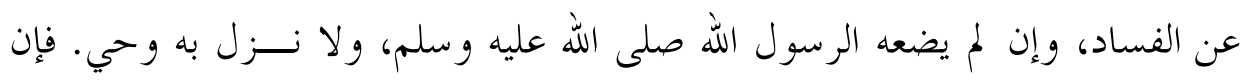

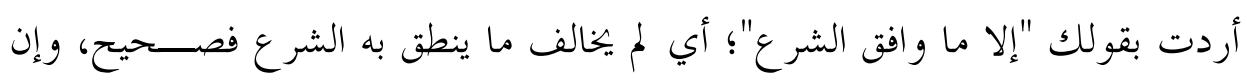

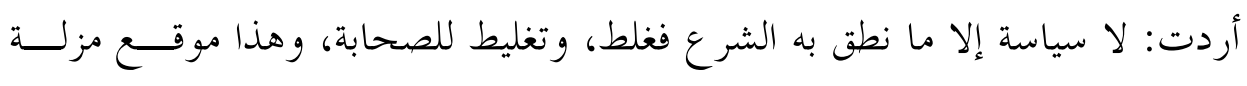

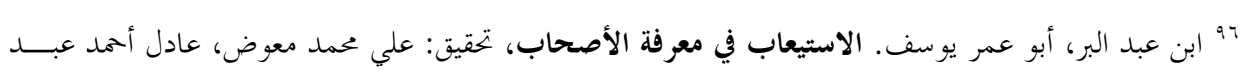

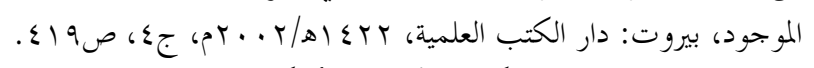

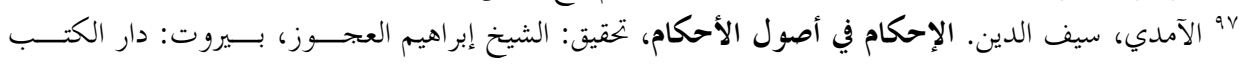


أقدام، و مضلة أفهام، وجعلوا الشريعة قاصرة لا تقوم بمصالح العباد محتاجة إلى غيرهـــا،

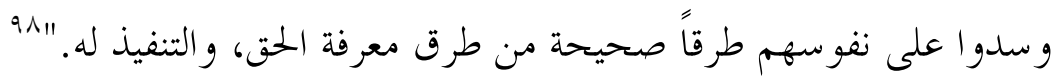

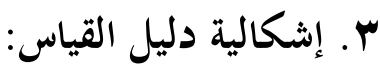

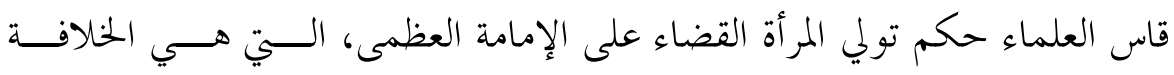

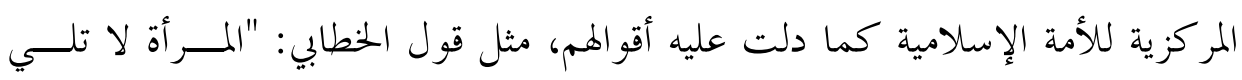
الإمارة، ولا القضاء،" "9 و الجامع بينهما "الولاية العامة".

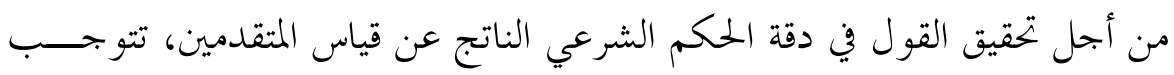
مقارنة مناط القضاء مع مناط الخلافة العظمى. فمناط الخلافة العظمى يمكن استخلاصه

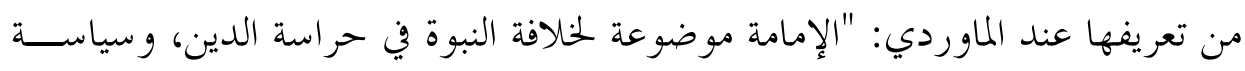
الدنيا." لم" وقول ابن عابدين: "رياسة عامة في الدين و الدنيا خحلافة عن البي صلى الله

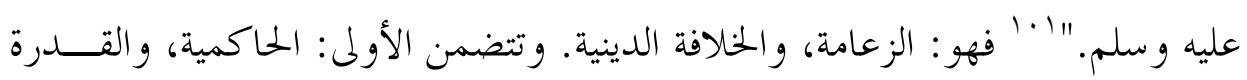
على الإلزام، وقيادة الجيوش، و الدفاع عن الديار . وتتضمن الثانية العلم الشرعي، بما فيه المعرفة بمقاصد الشريعة والعدل، و الاجتهاد، وإقامة الصلوات، و إصدار الفتاوى. فمناط

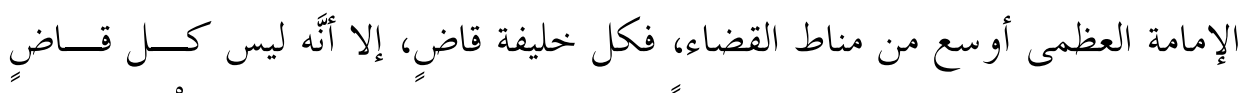

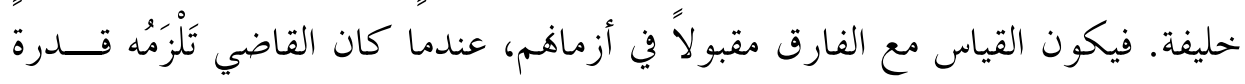

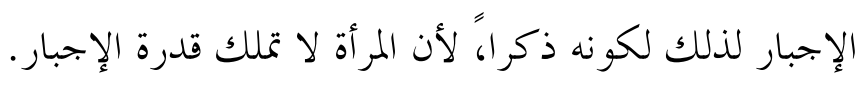

أما في الوقت الحاضر، وقد استقّر معنى القضاء على مفهوم واضح، وصريح، وهو

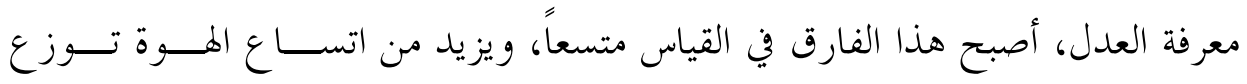

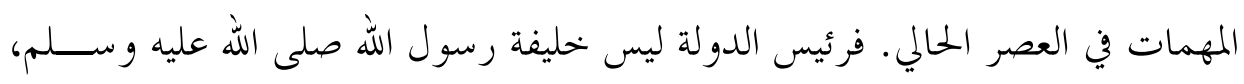

^^ ابن قيم الجوزية، أبو عبد الله محمد. الطرق الحكمية في السياسة الشرعية، تحقيق: محمد حامد الفقي، بيروت:

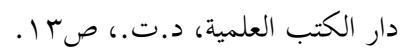

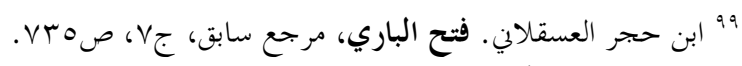

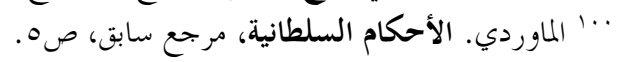

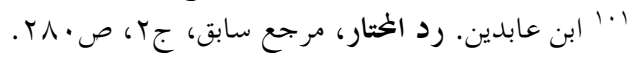


ولا يقيم الصلوات، ولا يقود الجيوش، ولا يحكم في الخصومات، ولا يصدر الفتاوى،

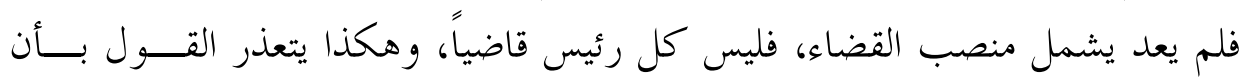
الحكم الشرعي لمنصب القضاء يمكن قياسه على الولاية العامة.

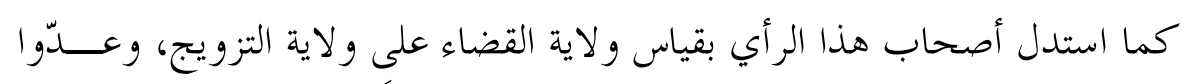

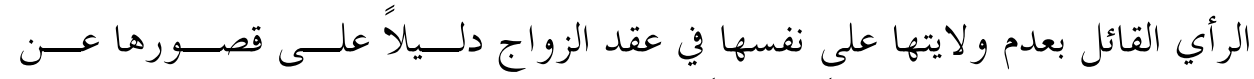

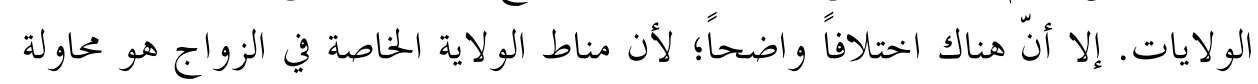

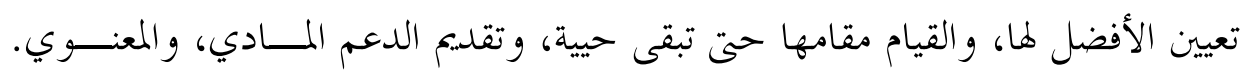

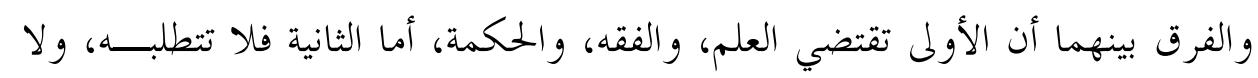
تقتضيه، و كم من و الد جاهل سفيه تولى عقد نكاح النتهـ ويضعف القياس وجود أربعة آراء في ولايتها على نفسها عند الزواج، نقله ابــن

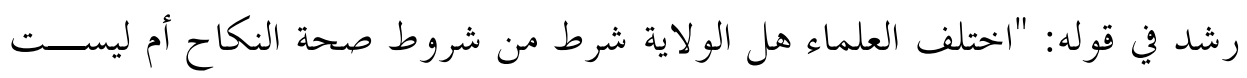

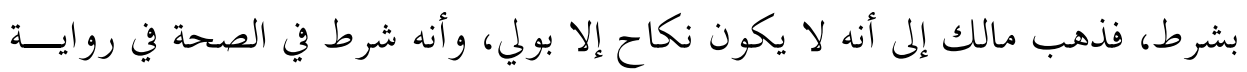

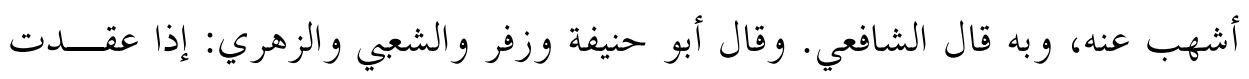

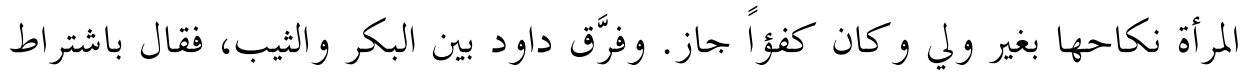

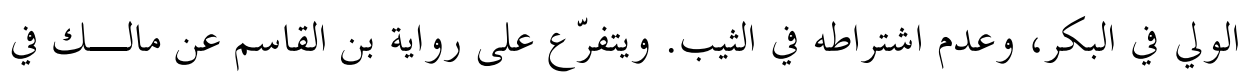

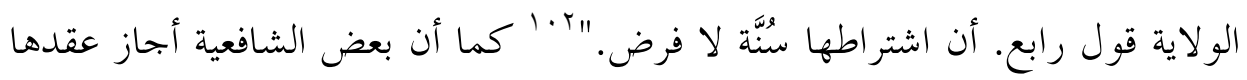
الأنكحة في حالة استيلائها على السلطة، كما في حاشية عميرة: "استثنى بعضهم ما لو لو

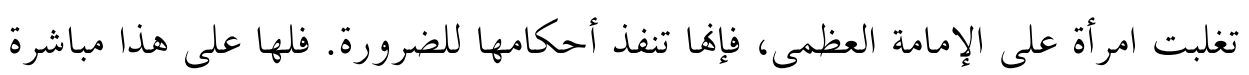

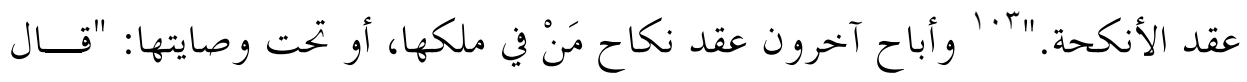

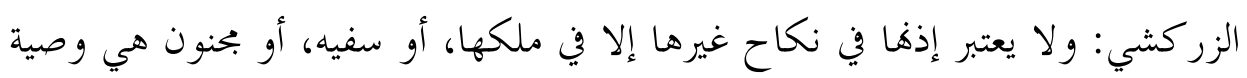
عليه. ". .

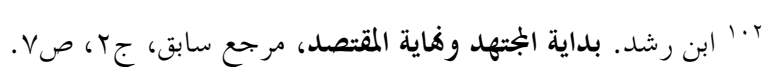

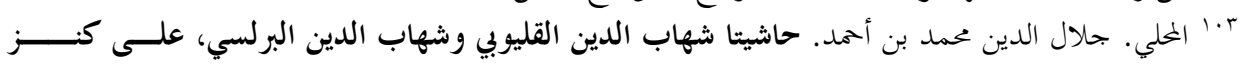

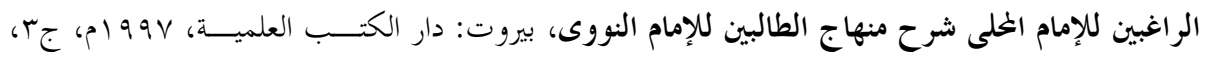




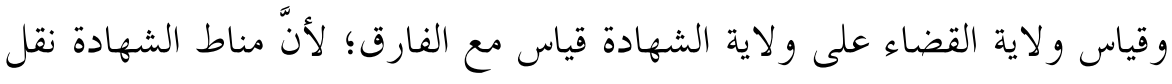

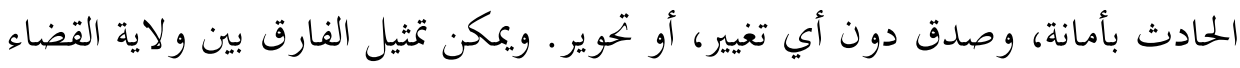

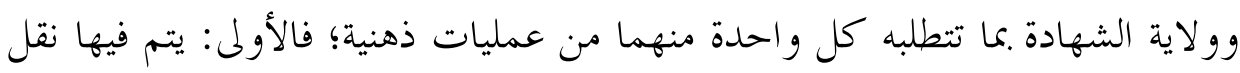

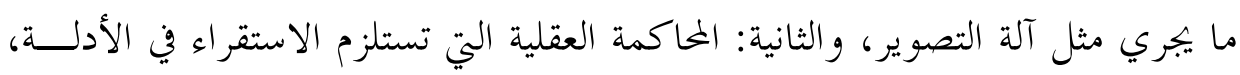

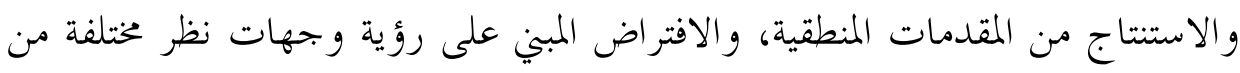

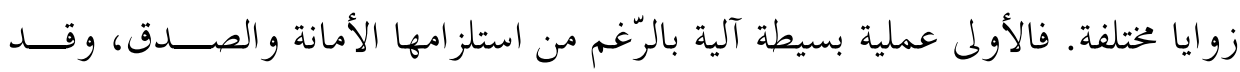

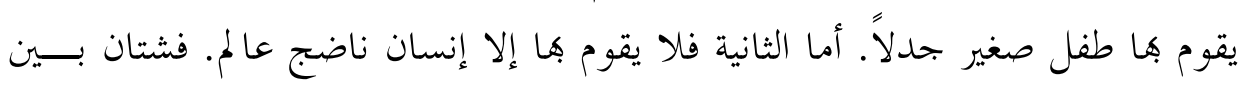

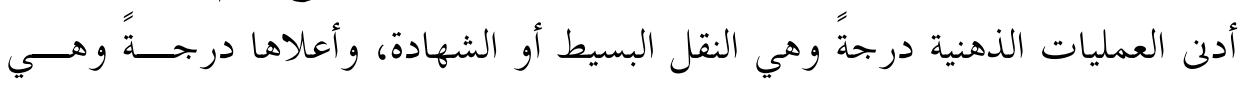

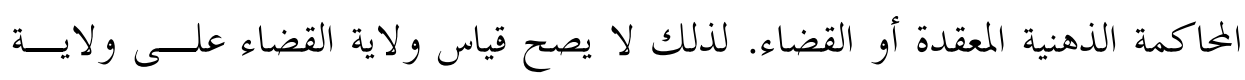
الشهادة.

ويضعِف هذا القياس اختلافُ العلماء في صحة نقص المرأة عن قبول الشهادات،

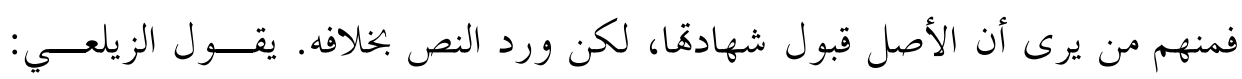

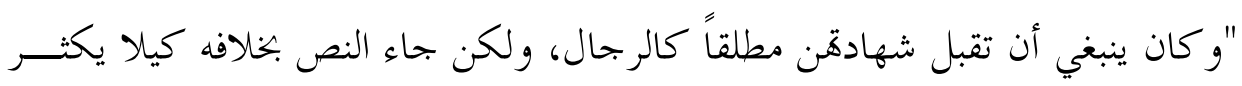

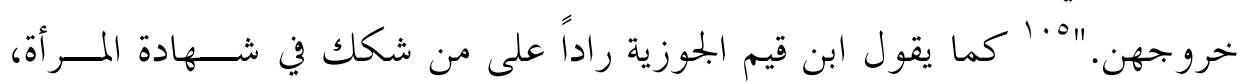

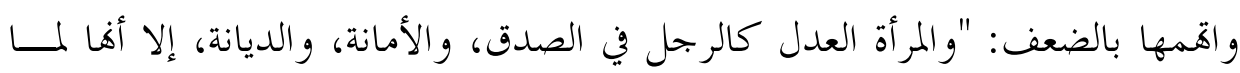

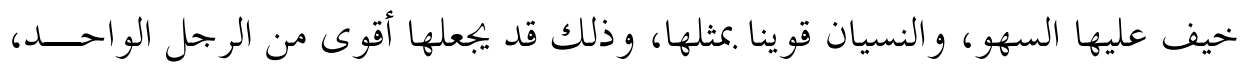
أو مثله. 1"T - أو

ويجيز ابن تيمية شهادة المرأة الواحدة عند الأداء؛ إذ يفرق بين التحمّــل و الأداء:

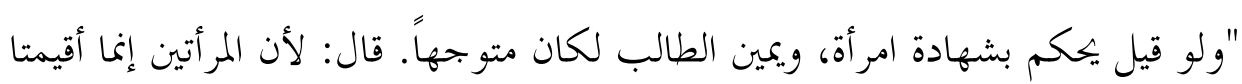

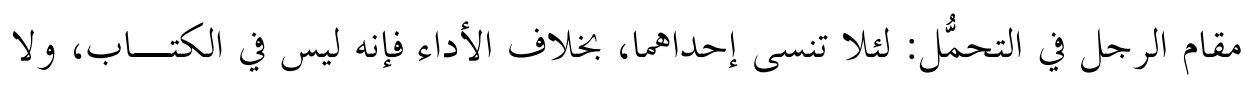

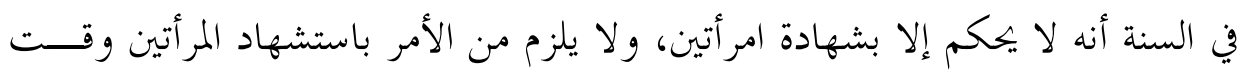

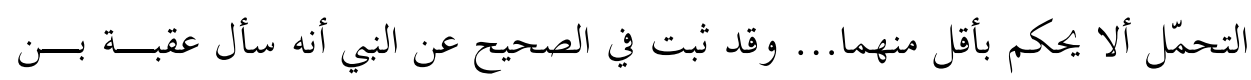

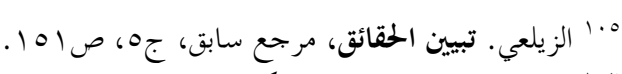

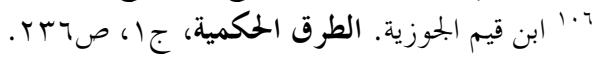


الحارث فقال: إي تزوجت امرأة فجاءت أمة سوداء، فقالت إها أرضعتنا، فأمره بفراق

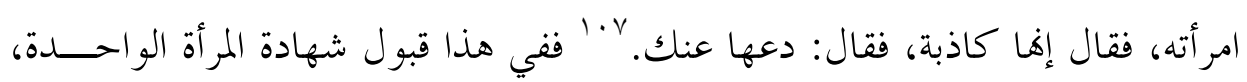

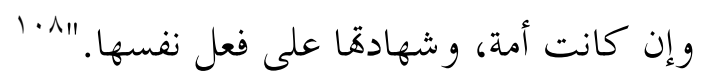

\section{ع. إشكالية الإطار الزمالي المكالي أوالعُرف السائد:}

بالرجوع إلى كتابات المتقدمين، يتبين أن هناك نظرة سائدة بين العلمـــاء حــــــ

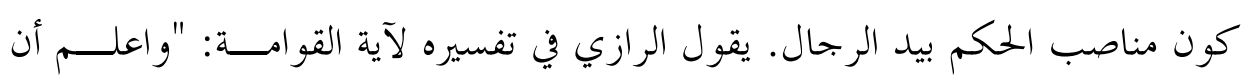
فضل الرجال على النساء حاصل من وجوه كثيرة، بعضها صفات حقيقية، وبعضــها

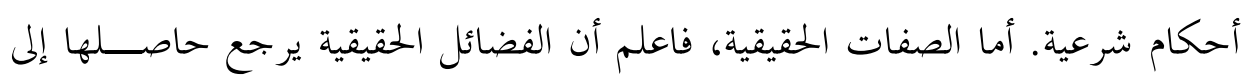

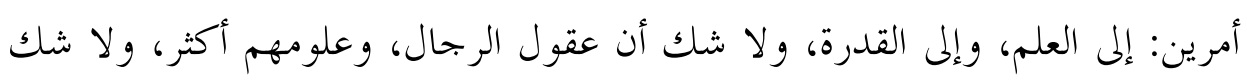

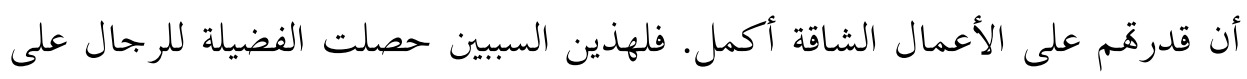

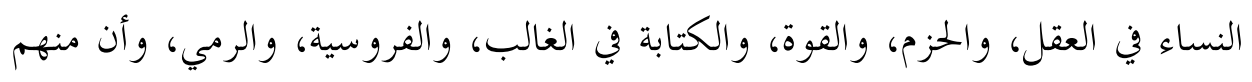

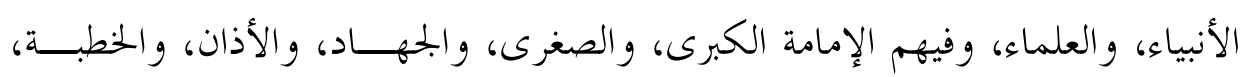

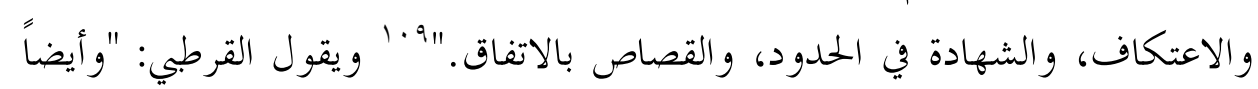

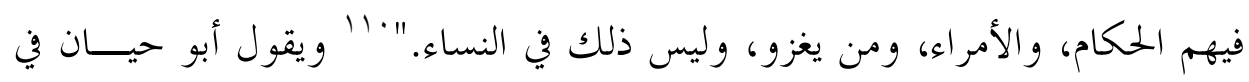

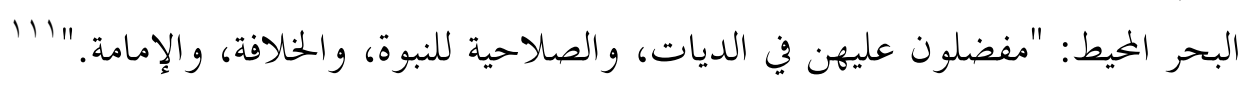

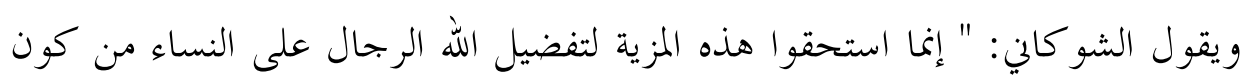

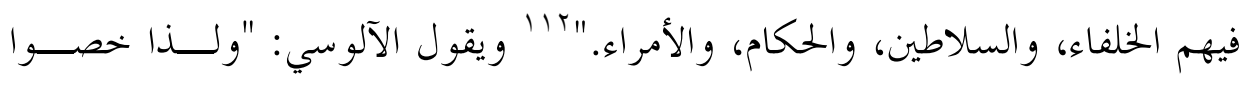

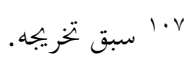

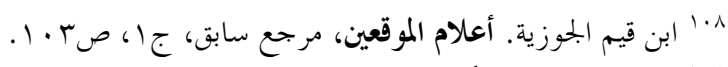

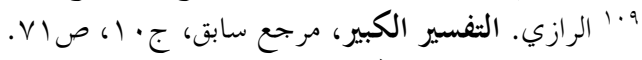

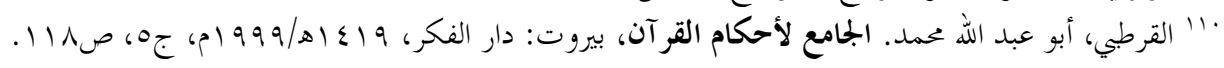

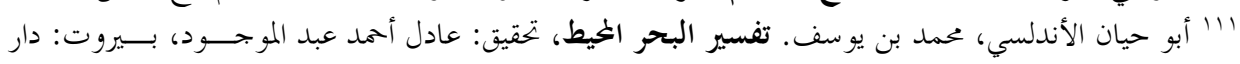

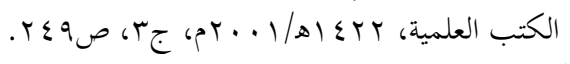

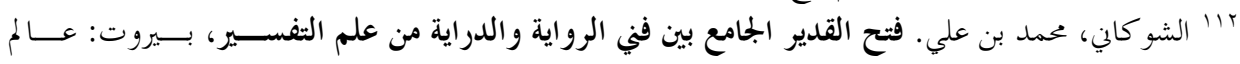

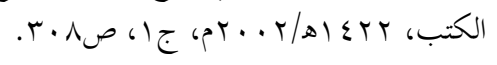


بالرسالة، و النبوة على الأشهر، و بالإمامة الكبرى، و الصغرى، وإقامـــة الشــعائر،...6

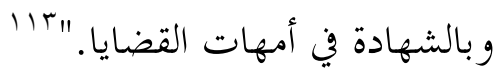

فالأعراف في ذلك الوقت، كانت تأبى حكم النساء، ولذلك تم تفسـير آيــات القرآن الكريم قطعية الثبوت والدلالة بحديث آحاد، وهو ما يخالف المنطق بشكل عام، والمنهج الأصولي بشكل خاص. والحديث يتعارض مع القرآن في مدحه ملكة ســبأ في موضــعين؛ الأول حسـين

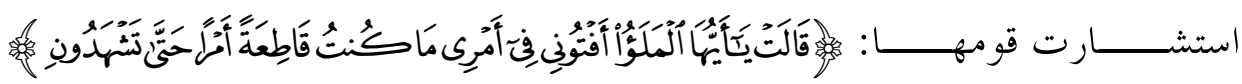

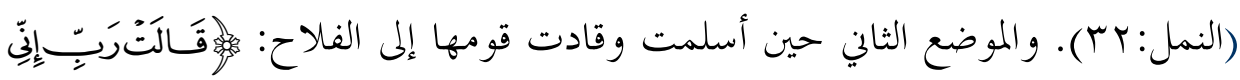

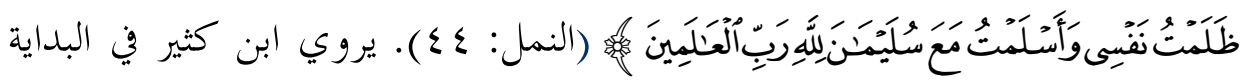

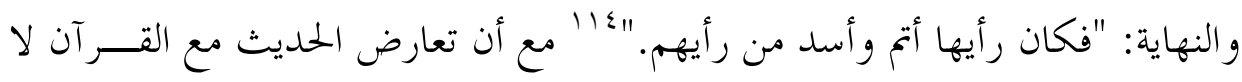

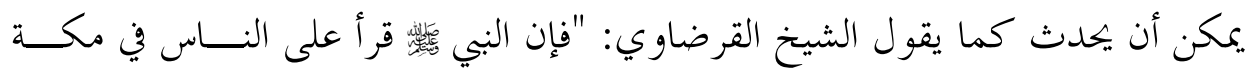
سورة النمل، وقص عليهم في هذه السورة قصة ملكة سبأ التي قادت قومها إلى الفلاح

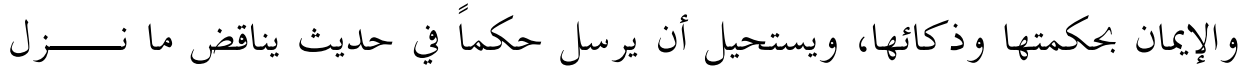
عليه من وحي." كما أنَّ دلالة الحمديث على الحهكم ليست قطعية عند الجمهـور؛ لأنــهـ ذكـــــه في

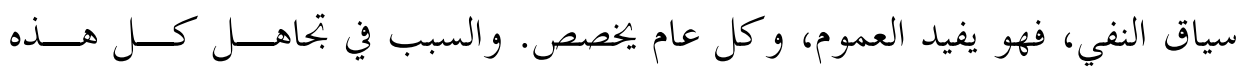
الإشكاليات التي أحاطت بالحديث -ومنها عدم سماع النبي صلى الله عليه وسلم بتولي

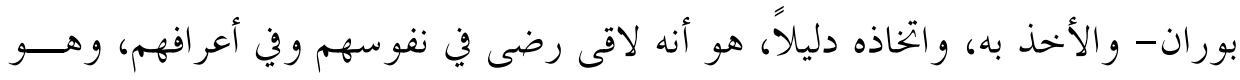
منع النساء من الولايات العامة، فولايتها سبب في عدم الفلاح، يقول الصنعاني: "فيـهـ

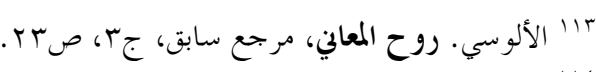

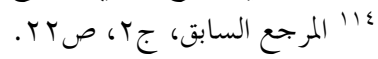

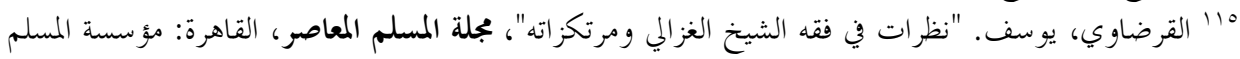

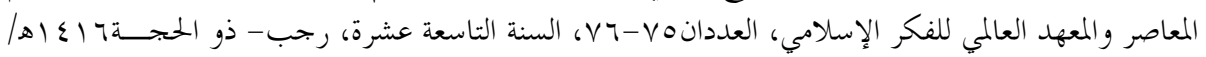




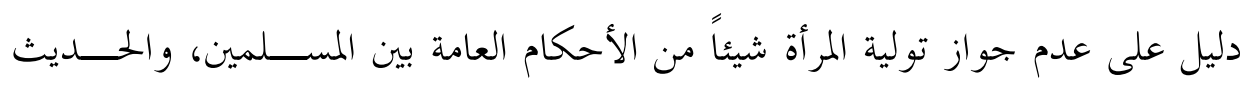

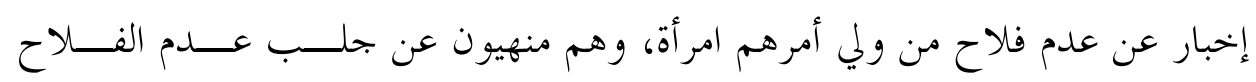

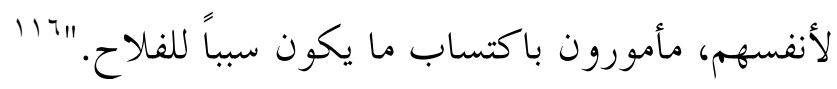
و باستقر اء التاريخ بجد أن بوران لم بحلب لقومها الهلاك، بل على العكس كانـــــ

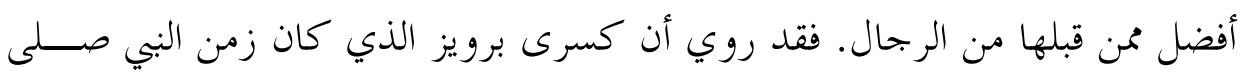
الله عليه وسلم علا، وتحبر، وظلم الرعية، و بلغ عدد السجناء في عصره خمسة و ثلاثين

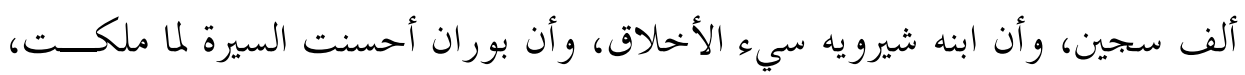

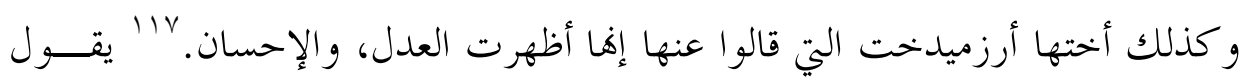

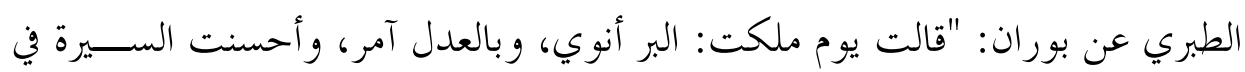

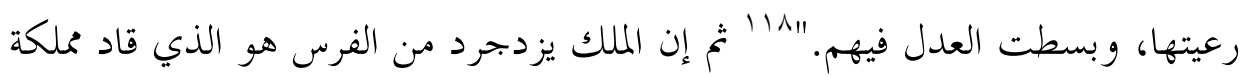

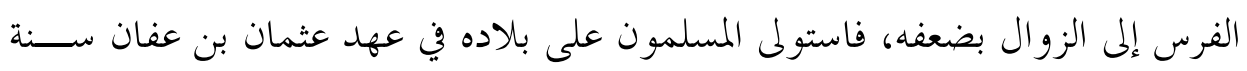
إحدى وثلاثين للهجرة: "كان آخر ملو كهم الذي سلب منه الملك يزدجرد بن شهريار

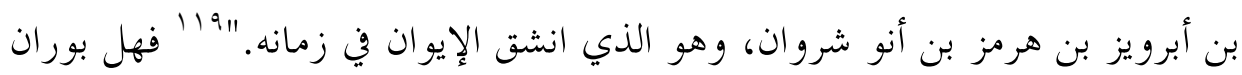

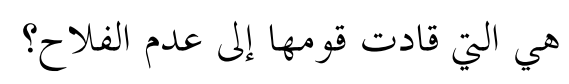

\section{خاتمة:}

أدَّى الاستقراء في تطوُر مهمَّة القضاء، عبر العصور الإسلامية المتتالية، إلى القــول

إنه تضمن ناحيتين أساسيتين؛ الأولى: القدرة على معرفة العدل، وهي ذهنية. والثانية: القدرة على الإلزام بالتنفيذ وهي مادية. ووع تطور الأنظمة السياسية تقلصت إلى قدرة واحدة تمثلت في القدرة الذهنية، فمناط القضاء هو العلم بالعدل. 1'11 الصنعاني، محمد بن إسماعيل. سبل السلام شرح بلوغ المرام من بمع أدلة الأحكام، بيروت: المكتبة العصرية،

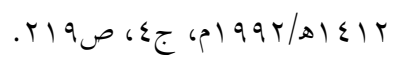

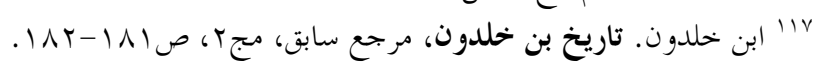

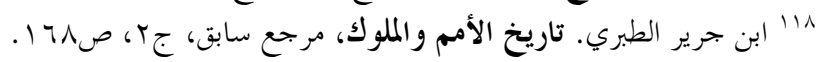

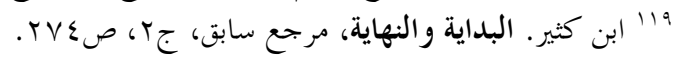




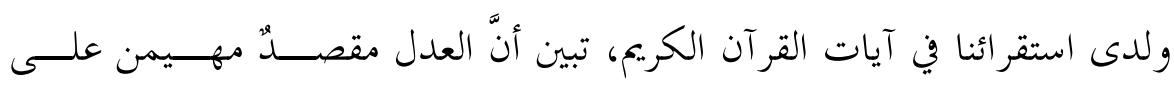

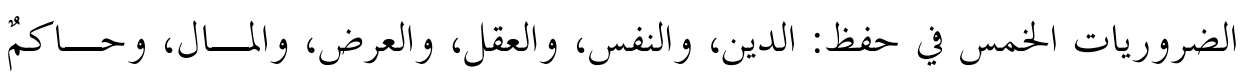

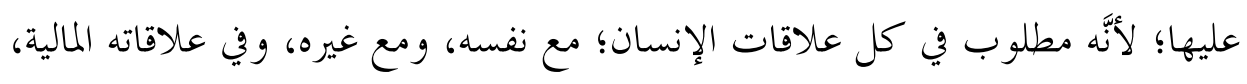

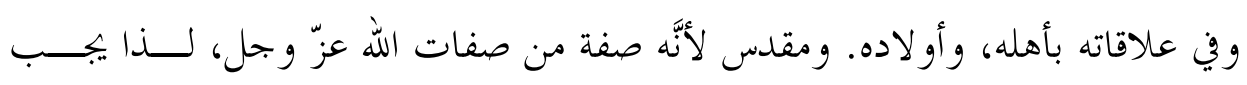

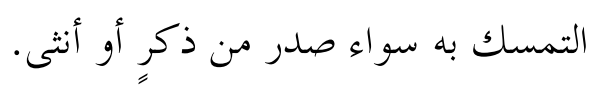
وأمكن استقراء أقوال الفقهاء وذهاهم إلى أربعة آراء متباينة؛ الرأي الأول: تحـــيم

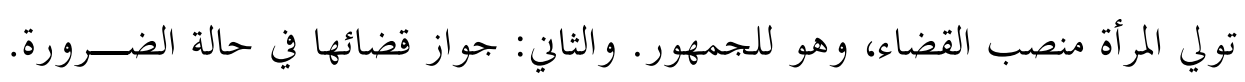

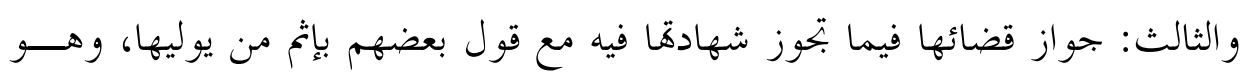

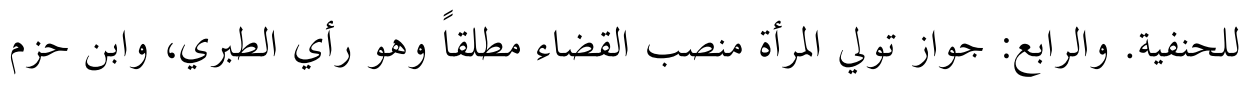

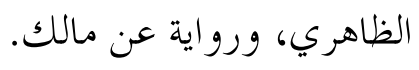

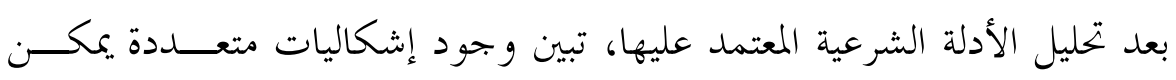

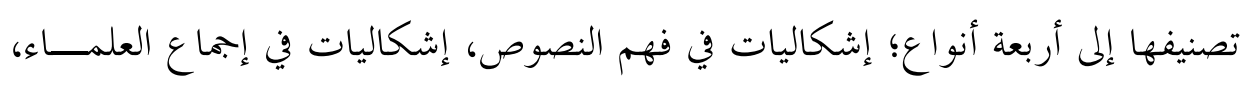
إشكاليات في دليل القياس، وإثكاليات ناشئة عن الخلفية الثقافية السائدة.

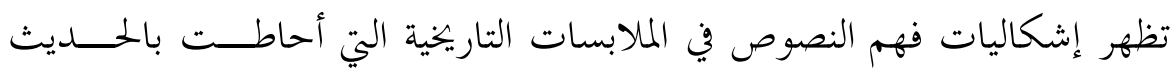

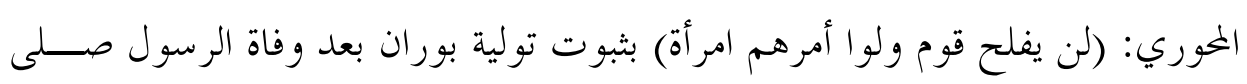

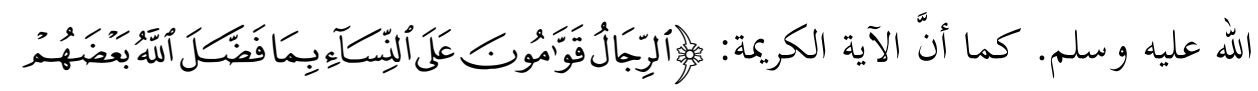

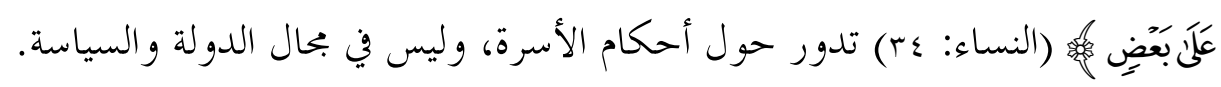
أماً دليل الإجماع، فقد نفى ابن رشد قيام الإجماع وأكد وجــــود آراء متعــدةدة.

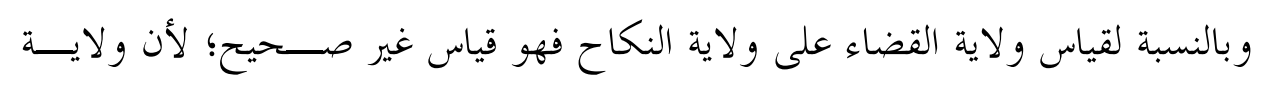

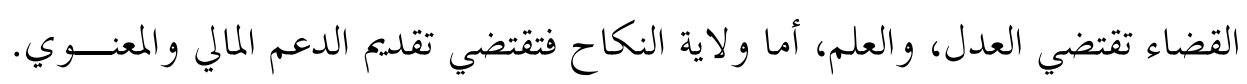

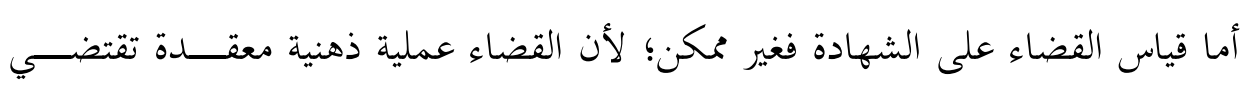




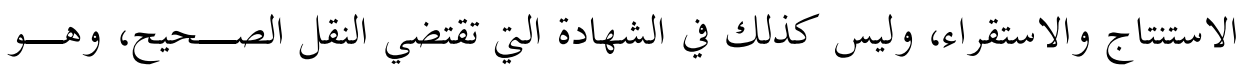
أبسط العمليات الذهنية.

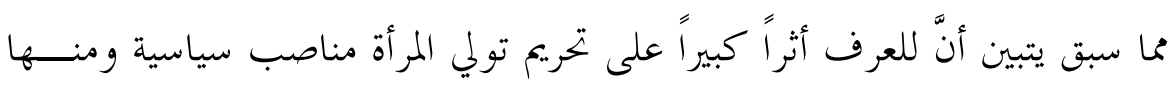

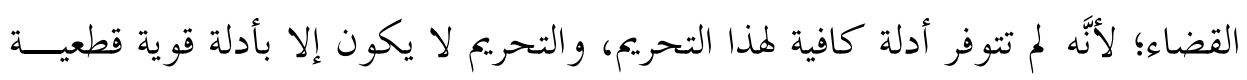

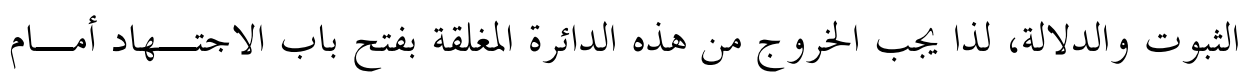

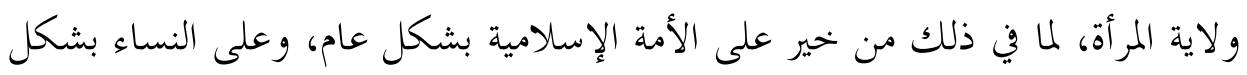
خاص. 